\title{
Oxidation Testing and Examination of AGR-2 TRISO Particles
}

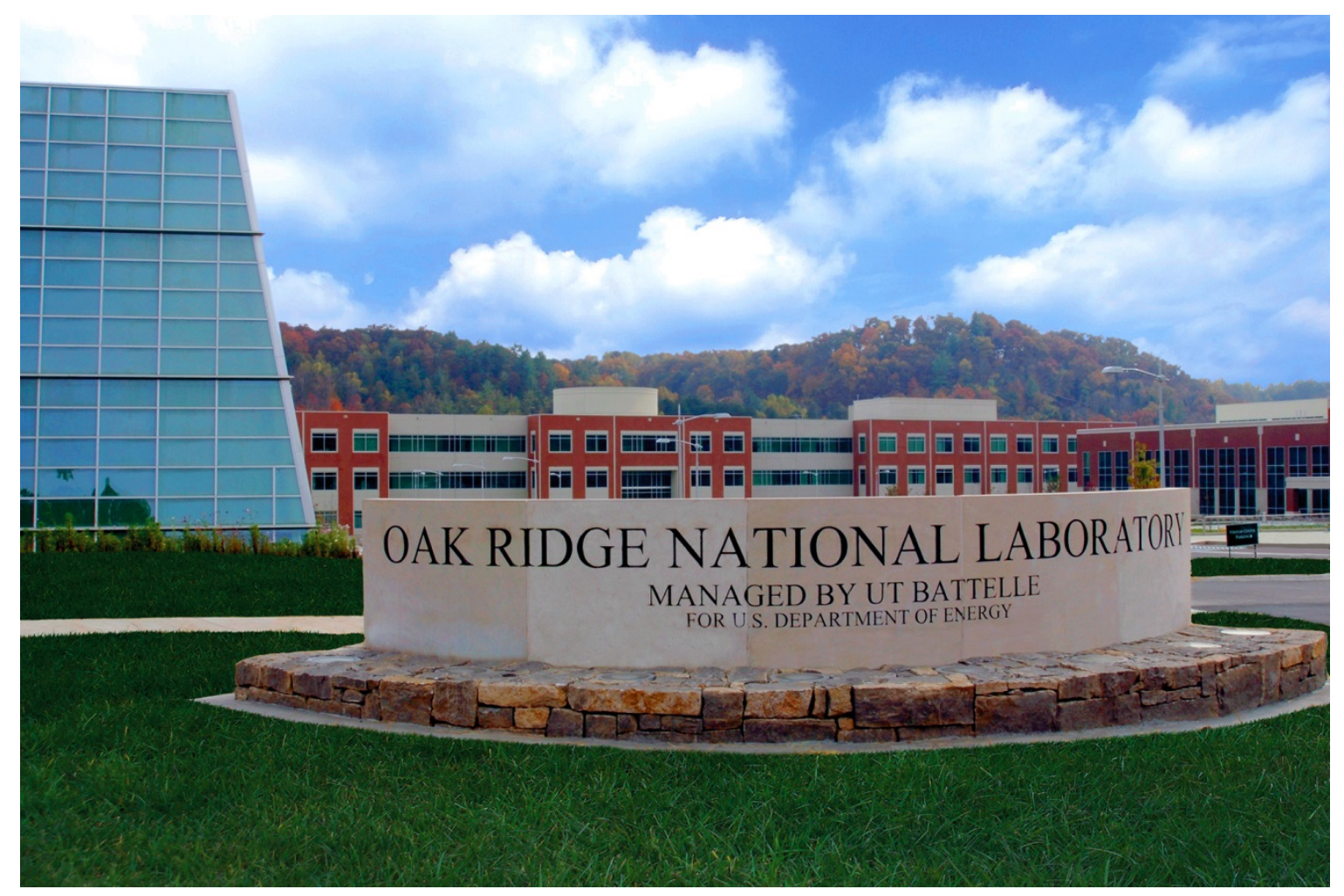

Darren J. Skitt

Rachel L. Seibert

Tyler J. Gerczak

John D. Hunn

Zachary M. Burns

Approved for public release.

Grant W. Helmreich

Distribution is unlimited.

September 2021 


\section{DOCUMENT AVAILABILITY}

Reports produced after January 1, 1996, are generally available free via US Department of Energy (DOE) SciTech Connect.

Website www.osti.gov

Reports produced before January 1, 1996, may be purchased by members of the public from the following source:

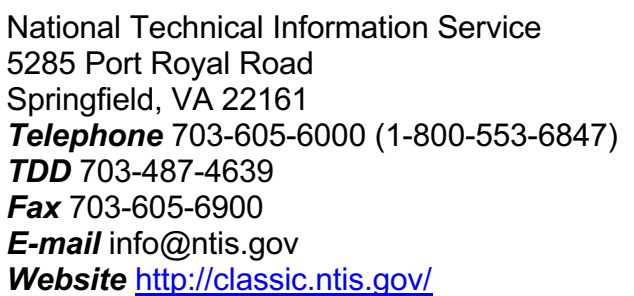

Reports are available to DOE employees, DOE contractors, Energy Technology Data Exchange representatives, and International Nuclear Information System representatives from the following source:

Office of Scientific and Technical Information

PO Box 62

Oak Ridge, TN 37831

Telephone 865-576-8401

Fax 865-576-5728

E-mail reports@osti.gov

Website https://www.osti.gov/

This report was prepared as an account of work sponsored by an agency of the United States Government. Neither the United States Government nor any agency thereof, nor any of their employees, makes any warranty, express or implied, or assumes any legal liability or responsibility for the accuracy, completeness, or usefulness of any information, apparatus, product, or process disclosed, or represents that its use would not infringe privately owned rights. Reference herein to any specific commercial product, process, or service by trade name, trademark, manufacturer, or otherwise, does not necessarily constitute or imply its endorsement, recommendation, or favoring by the United States Government or any agency thereof. The views and opinions of authors expressed herein do not necessarily state or reflect those of the United States Government or any agency thereof. 
Nuclear Energy and Fuel Cycle Division

\title{
OXIDATION TESTING AND EXAMINATION OF AGR-2 TRISO PARTICLES
}

\author{
Darren J. Skitt \\ Rachel L. Seibert \\ Tyler J. Gerczak \\ John D. Hunn \\ Zachary M. Burns \\ Grant W. Helmreich
}

September 2021

\author{
Prepared by \\ OAK RIDGE NATIONAL LABORATORY \\ Oak Ridge, TN 37831-6283 \\ managed by \\ UT-BATTELLE LLC \\ for the \\ US DEPARTMENT OF ENERGY \\ under contract DE-AC05-00OR22725
}





\section{CONTENTS}

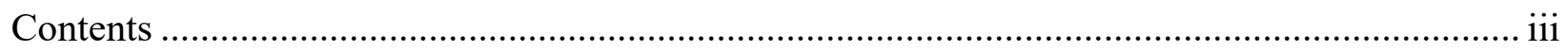

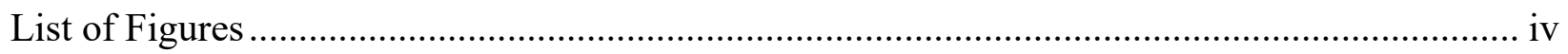

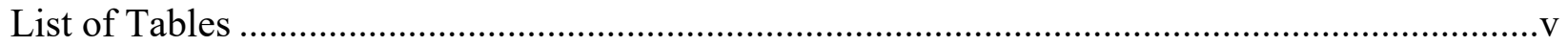

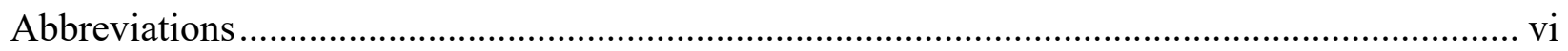

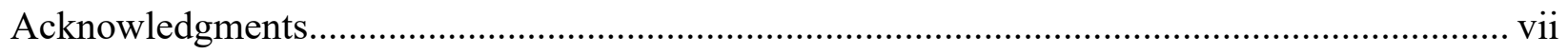

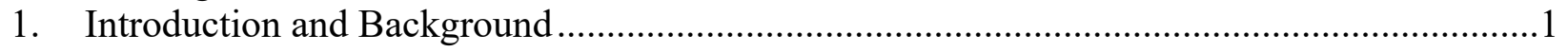

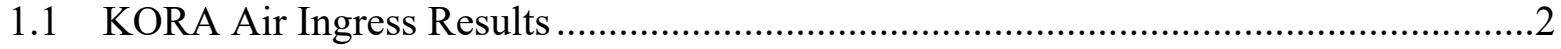

1.2 Oxidation Behavior of Polycrystalline Silicon Carbide ................................................

2. Experiment Objectives and Methods .........................................................................

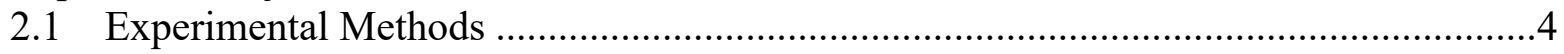

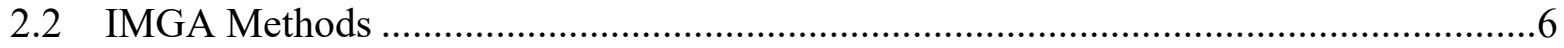

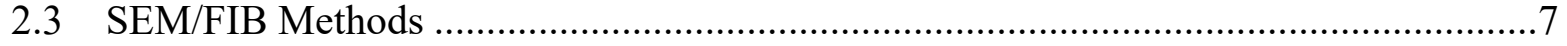

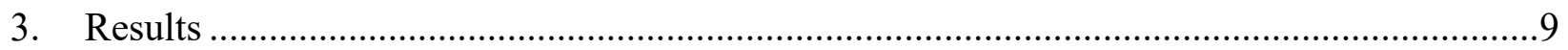

3.1 IMGA Results............................................................................................... 9

3.2 SEM/FIB Results...................................................................................... 13

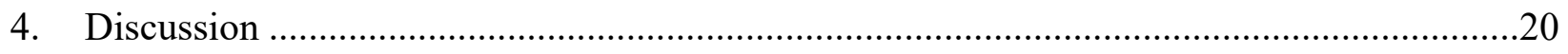

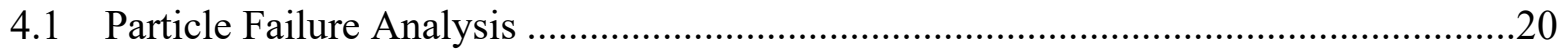

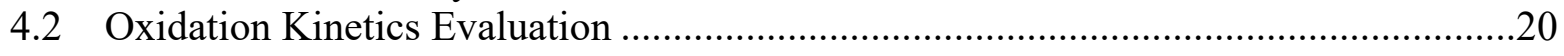

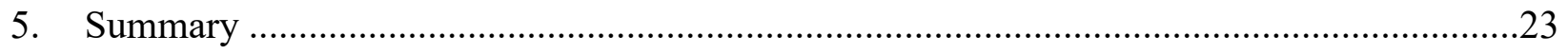

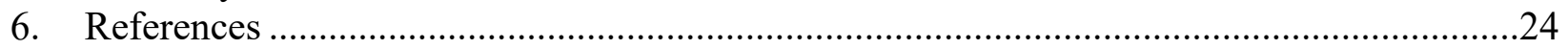




\section{LIST OF FIGURES}

Figure 1. SiC oxidation response with oxygen partial pressure vs. temperature.

Figure 2. FITT Furnace assembly: (a) 3D printed SiC cup, (b) alumina holder for SiC cup, (c) closed-end alumina tube for housing alumina holder, and (d) FITT with door ajar showing alumina tube position.

Figure $3 .{ }^{137} \mathrm{Cs} \mathrm{M} / \mathrm{C}$ histogram of Compact 5-4-2 (Hunn et al. 2018)........................................ 7

Figure 4. Example FITT particle on carbon tape for FIB/SEM analysis................................... 7

Figure 5. Example of mask applied over oxide layer to support automated thickness measurements.

Figure 6. Measured versus calculated inventory of ${ }^{137} \mathrm{Cs}$ for as-irradiated and oxidation-

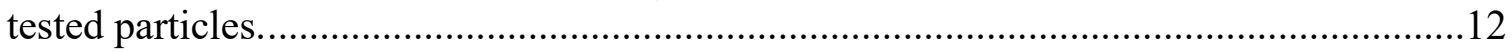

Figure 7. Particle failure fraction versus exposure time at $1400^{\circ} \mathrm{C}$.

Figure 8. Cross section and surface images of the $50 \mathrm{~h}$ unirradiated and irradiated FITT samples.

Figure 9. Cross section and surface images of the $100 \mathrm{~h}$ unirradiated and irradiated FITT samples.

Figure 10. Cross section and surface images of the $200 \mathrm{~h}$ unirradiated and irradiated FITT

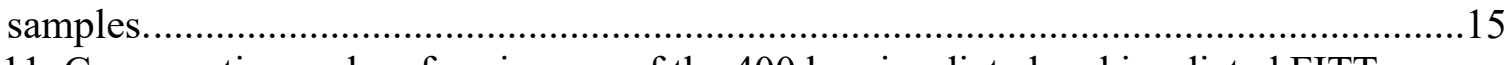

Figure 11. Cross section and surface images of the $400 \mathrm{~h}$ unirradiated and irradiated FITT samples.

Figure 12. Example of the secondary oxide found on some of the samples from $100 \mathrm{~h}$ unirradiated condition.

Figure 13. SEM image of the oxide layer from the (a) $400 \mathrm{~h}$ unirradiated and (b) $400 \mathrm{~h}$ irradiated samples.

Figure 14. Oxide thickness measurements for each exposure condition.

Figure 15. TEM images of the oxide regions from the (a) unirradiated and (b) irradiated samples, with corresponding diffraction patterns indicating that the unirradiated sample has an amorphous oxide layer and the irradiated sample has a crystalline oxide layer.

Figure 16. EDS mapping of the (a) $50 \mathrm{~h}$ irradiated sample and (b) an unirradiated sample, which show element locations within the chosen interface areas.

Figure 17. Oxide thickness squared vs. exposure time 


\section{LIST OF TABLES}

Table 1. Irradiation conditions for AGR-2 UCO Compact 5-4-2 ...............................................

Table 2. Calculated linear and parabolic oxidation rates of the SiC layer in TRISOcoated particles (Cao et al. 2020).

Table 3. Oxidizing test conditions for irradiated and unirradiated particles discussed in this report

Table 4. Oxidation test conditions planned for future studies of irradiated and unirradiated particles

Table 5. Results of measured activity of 44 randomly selected particles from

Compact 5-4-2 (Hunn et al. 2018)

Table 6. Measured activity of 10 irradiated particles from the $50 \mathrm{~h}$ oxidation test

Table 7. Measured activity of 15 particles recovered from the $100 \mathrm{~h}$ oxidation test.

Table 8. Measured activity of 18 particles recovered from the $200 \mathrm{~h}$ oxidation test.

Table 9. Measured activity of 13 particles recovered from the $400 \mathrm{~h}$ oxidation test.

Table 10. Oxide thickness for unirradiated and irradiated burn back particles after exposure to $50-400 \mathrm{~h}$

Table 11. Calculated parabolic rate constant, B, based on simple parabolic rate equation for different exposure ranges 


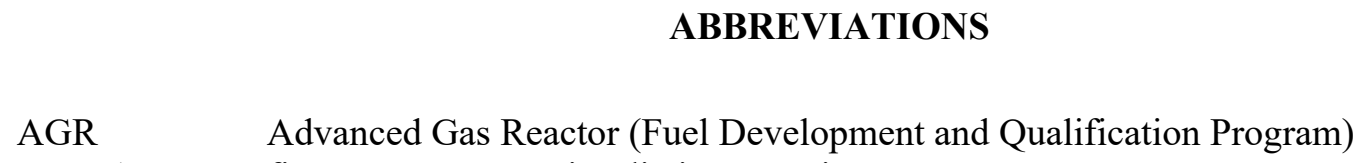




\section{ACKNOWLEDGMENTS}

This work was sponsored by the US Department of Energy Office of Nuclear Energy Advanced Reactor Technologies as part of the Advanced Gas Reactor Fuel Development and Qualification Program. Hot cell activities were supported by Oak Ridge National Laboratory (ORNL) Irradiated Fuels Examination Laboratory staff. The authors would like to acknowledge Andrew Kercher and Dr. Fred Montgomery for support with particle supply. 


\section{INTRODUCTION AND BACKGROUND}

Post-irradiation examination (PIE) oxidation testing is being performed at Oak Ridge National Laboratory (ORNL) on fuel particles from the second Advanced Gas Reactor (AGR) irradiation experiment (AGR-2). Tristructural isotropic (TRISO)-coated particles containing mixed uranium carbide and uranium oxide (UCO) fuel kernels were taken from AGR-2 Compact 5-4-2 and heated in the Furnace for Irradiated TRISO Testing (FITT) under varying oxidizing conditions. Details on Compact 5-4-2 PIE can be found in a previous report (Hunn et al. 2018).

This report presents and discusses results from four oxidation tests of individual irradiated Compact 5-4-2 particles and unirradiated AGR-2 UCO fuel particles as control samples. Before testing in the FITT, all particles had their outer pyrolytic carbon (OPyC) layer removed, as discussed in Section 2.1. Irradiation conditions for Compact 5-4-2 are presented in Table 1. Procedures for operation and handling of the particles in the FITT were established for irradiated TRISO particles. Prior work focused on long-term thermal exposure in inert atmosphere: sixteen unique FITT thermal testing runs with varying temperatures and durations were completed to examine fission product release behavior through the intact silicon carbide ( $\mathrm{SiC}$ ) layer. Details on this study can be found in AGR-2 Loose Particle Heating Tests in the Furnace for Irradiated TRISO Testing (Gerczak et al. 2020).

Table 1. Irradiation conditions for AGR-2 UCO Compact 5-4-2

\begin{tabular}{|c|c|c|c|c|c|}
\hline Compact ID $^{a}$ & Fabrication ID $^{b}$ & Fuel type & $\begin{array}{l}\text { Average burnup }{ }^{c} \\
\text { (FIMA) }\end{array}$ & $\begin{array}{l}\text { Fast fluence }{ }^{c} \\
(E>0.18 \mathrm{MeV})\end{array}$ & $\begin{array}{l}\text { TAVA } \\
\text { Temperature }\end{array}$ \\
\hline AGR-2 5-4-2 & LEU09-OP2- Z059 & $\mathrm{UCO}$ & $12.03 \%$ & $3.14 \times 10^{25} \mathrm{n} / \mathrm{m}^{2}$ & $1071^{\circ} \mathrm{C}$ \\
\hline
\end{tabular}

\footnotetext{
${ }^{a}$ The X-Y-Z compact identification (ID) convention denotes the location in the irradiation test train: Capsule-Level-Stack.

${ }^{b}$ Physical properties data for individual compacts are available and referenced to fabrication ID (Hunn, Montgomery, and Pappano 2010, pages 60-69).

${ }^{c}$ Burnup (Sterbentz 2014, table 6) and fast fluence (Sterbentz 2014, table 12) are based on physics calculations.

${ }^{d}$ Time-averaged, volume-averaged (TAVA) temperature is based on thermal calculations (Hawkes 2014, table 3).
}

The SiC layer in a TRISO-coated particle acts as a barrier against fission product release during irradiation and provides structural integrity. A weakened or failed $\mathrm{SiC}$ layer can allow fission products to be released from the particle (Hunn et al. 2016) into the OPyC, matrix, structural materials, and beyond. Silicon carbide can become degraded and fail during irradiation or subsequent safety testing; in AGR UCO TRISO fuel, this was observed to primarily occur via fission product attack originating at the inner pyrolytic carbon (IPyC)/SiC boundary (Hunn et al. 2016), but the occurrence of this type of degradation is rare. The upper bounds (at 95\% confidence interval) of $\mathrm{SiC}$ failure fraction of particles in the first AGR irradiation experiment (AGR-1) were $\leq 3.1 \mathrm{E}-5$ and $\leq 2.4 \mathrm{E}-5$ for as-irradiated compacts and $1600^{\circ} \mathrm{C}$ safety tested compacts, respectively (Demkowicz et al. 2015). Additionally, upper bounds of SiC failure fraction in the AGR-2 irradiation experiment were $\leq 1.04 \mathrm{E}-4$ and $\leq 1.58 \mathrm{E}-4$ for as-irradiated compacts and $1600^{\circ} \mathrm{C}$ safety tested compacts, respectively (Stempien et al. 2021). However, the SiC layer can be externally weakened via oxidation if oxygen is present from an air ingress accident in the core of a high temperature gas-cooled reactor (HTGR) and this oxygen reaches the surface of the SiC layer. Fission product release caused by an oxidized and failed $\mathrm{SiC}$ layer during an accident scenario in an HTGR is a potentially severe consequence. 
The formation and behavior of $\mathrm{SiO}_{2}$ was primarily of interest in the oxidation tests. $\mathrm{SiO}_{2}$ is a reaction product resulting from exposure of $\mathrm{SiC}$ to oxidizing atmospheres at elevated temperatures, as shown in Eq. (1). This reaction occurs in the passive regime of $\mathrm{SiC}$ exposure to oxygen atmospheres. However, in low oxygen, partial-pressure atmospheres and temperatures exceeding $\sim 1300^{\circ} \mathrm{C}$ (both possible in an HTGR accident scenario), the $\mathrm{SiC}$ layer is converted to volatile $\mathrm{SiO}(\mathrm{g})$ and $\mathrm{CO}(\mathrm{g})$ (Eq. [2]) in the active regime (IAEA 1997). Figure 1 shows the expected oxidation response of $\mathrm{SiC}$ with varying temperature and partial oxygen pressure.

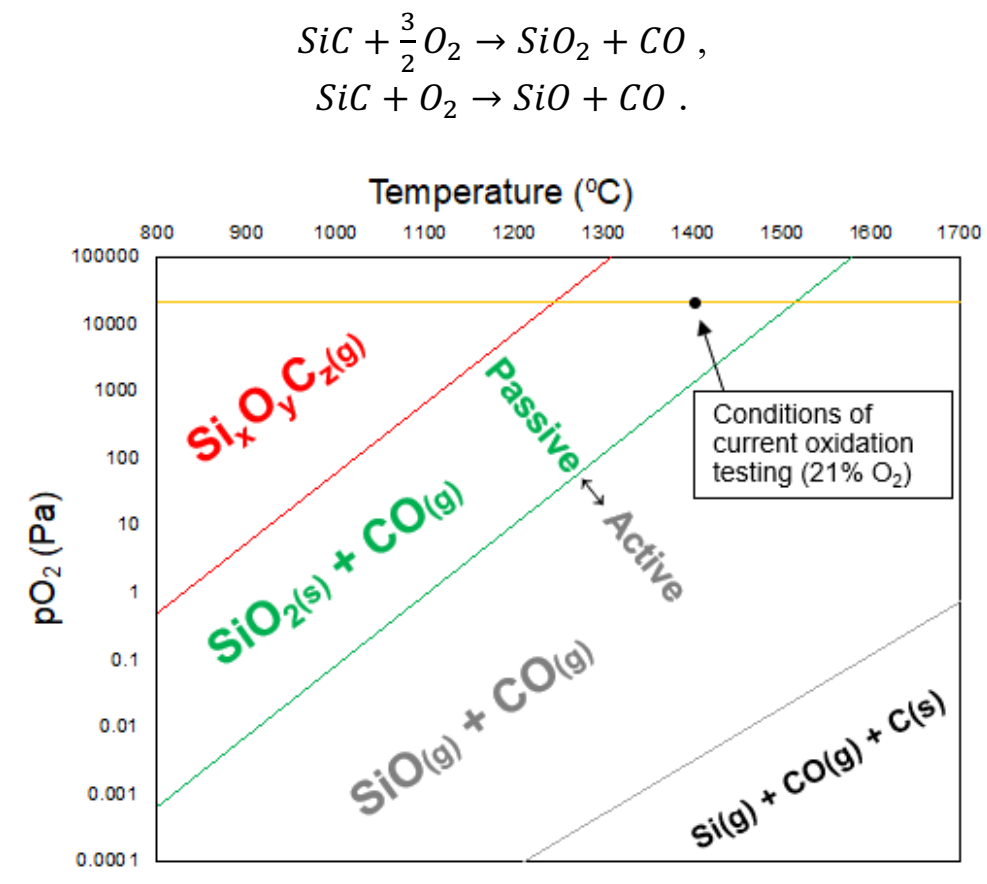

Figure 1. SiC oxidation response with oxygen partial pressure vs. temperature. The figure was extrapolated from data taken from Presser and Nickel (2008).

Another focus of the oxidation tests was on understanding the oxidation behavior and performance of irradiated $\mathrm{SiC}$ compared to those of unirradiated $\mathrm{SiC}$. Although the differences are not fully understood, a previous experiment suggested that oxidation rates may be accelerated by the presence of impurities in $\mathrm{SiC}$ (Singhal and Lange 1975). It is hypothesized that the presence of fission products, such as fission products traversing a fully intact SiC layer during irradiation (Gerczak et al. 2018) and transmutation products in the $\mathrm{SiC}$ layer, may affect the resultant microstructure of the $\mathrm{SiO}_{2}$ phase formed during oxidation in the passive regime. The impurities may result in formation of varying oxide microstructures that impact transport of oxygen through the passive oxide layer.

\subsection{KORA AIR INGRESS RESULTS}

Post-irradiation examinations of water vapor and air ingresses in an HTGR accident scenario have been conducted (Moormann 2011; IAEA 1997). Operational until 1996, the corrosion apparatus (KORA) was a German facility designed to monitor particle failure rates in oxidizing air and steam environments.

Particle failure was quantified by measuring the release of ${ }^{85} \mathrm{Kr}$, a well-retained gaseous fission product in coated particle fuel. For air ingress tests, $\mathrm{UO}_{2}$ TRISO fuel sphere elements and batches of TRISO particles irradiated at 9.2\% FIMA, compared to 12.03\% FIMA for the AGR-2 Compact 5-4-2 particles, were exposed to temperatures ranging from 1300 to $1600^{\circ} \mathrm{C}$ for up to $400 \mathrm{~h}$ with an air flow rate of $30 \mathrm{~L} / \mathrm{h}$ (IAEA 1997). In these KORA tests, particle failure fraction in the fuel spheres became significant at $1300^{\circ} \mathrm{C}$, and by $1600^{\circ} \mathrm{C}$, particles in both fuel spheres and coated particle batches immediately failed 
when exposed to air. The KORA experiments served as a baseline to develop a test matrix in which particle failure behavior from AGR-2 irradiated particles could be compared with the literature.

\subsection{OXIDATION BEHAVIOR OF POLYCRYSTALLINE SILICON CARBIDE}

Oxidation kinetics and behavior of $\mathrm{SiC}$ have been studied previously, and Costello and Tressler (1986) exposed single-crystal and polycrystalline $\mathrm{SiC}$ to high-purity oxygen at $1200-1500^{\circ} \mathrm{C}$ for up to $24 \mathrm{~h}$. It was observed that sintered $\alpha-\mathrm{SiC}$ experiences linear-parabolic oxidation behavior, modeled by Deal and Grove (1965), up to $10 \mathrm{~h}$ at $1400^{\circ} \mathrm{C}$, but longer exposures result in a decrease in oxide formation rate. Furthermore, higher temperatures led to decreased oxidation rates at shorter times. The decrease in oxidation rate has been theorized to be the result of slower oxygen transport through the crystalline oxide phases as opposed to through amorphous phases (Costello and Tressler 1986).

In the study by Costello and Tressler (1986), hot-pressed polycrystalline $\mathrm{SiC}$ at temperatures above $1200^{\circ} \mathrm{C}$ experienced linear-parabolic oxidation growth for the first $10 \mathrm{~h}$ of exposure. However, exposure times past $10 \mathrm{~h}$ indicated decreasing and increasing fluctuations in oxide growth rate, which were attributed to the complex crystallization nature of the oxide layer. Competing with oxidant transport through crystalline and amorphous phases, higher impurity concentrations (Singhal and Lange 1974) and higher nucleation site densities contributed to an increased deviation from the parabolic oxidation rate (Costello and Tressler 1986).

In addition to bulk $\mathrm{SiC}$ samples, oxidation behavior of TRISO-coated $\mathrm{SiC}$ in proposed air ingress accident conditions of HTGRs has been studied (Cao et al. 2020). In the Cao et al. (2020) study, TRISO-coated zirconia kernels were exposed to atmospheric oxygen at $900-1400^{\circ} \mathrm{C}$ for up to $48 \mathrm{~h}$. Although no oxide layer was observed below $1100^{\circ} \mathrm{C}$ after $24 \mathrm{~h}$, an amorphous silica layer was observed in the $1200-1300^{\circ} \mathrm{C}$ range, and a more complex crystalline phase was detected at $1400^{\circ} \mathrm{C}$. At longer exposure times of $48 \mathrm{~h}$, oxidation began to occur at $1100^{\circ} \mathrm{C}$, and increasing oxidation rates were observed with increasing temperature. Much like the hot-pressed and sintered $\mathrm{SiC}$ in the study performed by Costello and Tressler (1986), the Deal-Grove model was applied to describe the linear-parabolic oxidation nature of TRISOcoated $\mathrm{SiC}$ at $1200-1400^{\circ} \mathrm{C}$, and results are replicated in Table 2.

Table 2. Calculated linear and parabolic oxidation rates of the SiC layer in TRISO-coated particles (Cao et al. 2020)

\begin{tabular}{lcc}
\hline Temperature $\left({ }^{\circ} \mathrm{C}\right)$ & $\begin{array}{c}\text { Linear oxidation } \\
\text { rate }(\mu \mathrm{m} / \mathrm{h})\end{array}$ & $\begin{array}{c}\text { Parabolic oxidation } \\
\text { rate }\left(\mu \mathrm{m}^{2} / \mathrm{h}\right)\end{array}$ \\
\hline 1200 & 0.030 & 0.017 \\
1300 & 0.058 & 0.042 \\
1400 & 0.125 & 0.121 \\
\hline
\end{tabular}

Previous studies by Cao et al. (2020) and Costello and Tressler (1986) provided key observations for oxide characterization of unirradiated $\mathrm{SiC}$, primarily highlighting the complex nature of oxide crystallization and growth in the passive regime. The oxidation tests presented in this report aimed to expand previous observations and analysis to irradiated $\mathrm{SiC}$ by directly comparing oxidation behavior between irradiated and unirradiated TRISO particles. The simultaneous exposure will provide insight into the impact of irradiations on oxidation given the differences in $\mathrm{SiC}$ layer microstructure and composition stemming from fission/transmutation product presence and $\mathrm{SiC}$ irradiation damage. 


\section{EXPERIMENT OBJECTIVES AND METHODS}

The oxidation tests presented in this report expanded on previous FITT thermal exposure tests (Gerczak et al. 2020) by exploring the response of AGR-2 coated particles in an oxidizing atmosphere. The goals of these tests were to

- measure particle failure rate and time to failure as a function of exposure time,

- understand oxidation behavior of the $\mathrm{SiC}$ layer in irradiated and unirradiated particles for varying exposure durations at $1400^{\circ} \mathrm{C}$,

- analyze oxidation microstructure in individual particle samples, and

- develop insights on differences in oxidation kinetics of irradiated $\mathrm{SiC}$ relative to those of unirradiated $\mathrm{SiC}$.

\subsection{EXPERIMENTAL METHODS}

Each test consisted of ten Compact 5-4-2 particles and ten as-fabricated AGR-2 UCO particles exposed to $1400^{\circ} \mathrm{C}$ in an atmosphere containing $21 \% \mathrm{O}_{2}$ (balance $\mathrm{N}_{2}$ ). Table 3 shows the experimental conditions for the scope of this report. Additional tests are planned to further understand the relationship between temperature and oxygen partial pressures in $\mathrm{SiC}$ oxidation, and the conditions are presented in Table 4.

Table 3. Oxidizing test conditions for irradiated and unirradiated particles discussed in this report

\begin{tabular}{llllll}
\hline Temperature & Atmosphere & \multicolumn{4}{c}{ Time } \\
$1400^{\circ} \mathrm{C}$ & $21 \% \mathrm{O}_{2}\left(\right.$ balance $\left.\mathrm{N}_{2}\right)$ & $50 \mathrm{~h}$ & $100 \mathrm{~h}$ & $200 \mathrm{~h}$ & $400 \mathrm{~h}$ \\
\hline
\end{tabular}

Table 4. Oxidation test conditions planned for future studies of irradiated and unirradiated particles

\begin{tabular}{lll}
\hline Temperature & Atmosphere & Time \\
$1200^{\circ} \mathrm{C}$ & $21 \% \mathrm{O}_{2}\left(\right.$ balance $\left.\mathrm{N}_{2}\right)$ & $400 \mathrm{~h}$ \\
$1400^{\circ} \mathrm{C}$ & $2 \% \mathrm{O}_{2}$ (balance $\left.\mathrm{He}\right)$ & $400 \mathrm{~h}$ \\
\hline
\end{tabular}

Individual Compact 5-4-2 particles were selected after their OPyC layer had been "burned back," thereby exposing the $\mathrm{SiC}$ layer. The process for obtaining the individual TRISO particles from the deconsolidation leach-burn-leach (DLBL) procedure is described in a previous report (Hunn et al. 2013). Initially, the fuel compact was electrolytically deconsolidated in nitric acid to collect particles and matrix debris. After deconsolidation, the particles and matrix material underwent two preburn $24 \mathrm{~h}$ leaches in boiling nitric acid. An additional nitric acid boil was performed to remove any residual matrix overcoat from the OPyC layer. The particles were then separated from the matrix residue by rinsing the material through a stainless-steel sieve stack. The particles were examined by the Irradiated Microsphere Gamma Analyzer (IMGA), which is described in Section 2.2. After IMGA examination, $\sim 90 \%$ of the particles were returned to be burned in air at $750^{\circ} \mathrm{C}$ for $72 \mathrm{~h}$, during which period their OPyC layer was burned off. The post-burn particles then underwent two additional $24 \mathrm{~h}$ leaches. Unirradiated control particles were selected from the same fabrication composite used to create Compact 5-4-2. Similar, but not identical, steps were followed to obtain unirradiated AGR-2 burnback particles. Compact LEU09-OP2-Z002 (Hunn et al. 2010), was deconsolidated to liberate particles. The individual particles were burned in air at $750^{\circ} \mathrm{C}$ for $72 \mathrm{~h}$ and subjected to a $24 \mathrm{~h}$ acid leach and rinse. The recovered particles were used as a control 
sample to compare with simultaneously exposed irradiated Compact 5-4-2 particles. Oxidation stemming from the burn step is not expected to compromise the $\mathrm{SiC}$ layer as particle failure analysis postburn showed no significant increase in failure fraction compared to as-coated particles not subjected to compacting and a burn step (Hunn et al. 2010). The burn stage is not expected to impact oxidation kinetics analysis as the expected oxide thickness after these exposure conditions would be $<0.01 \mu \mathrm{m}$ based on extrapolated kinetics for TRISO-SiC (Cao et al. 2020).

The general process outlined in the standard operating procedure for FITT operation (NFM-PIE-SOG-01, Rev. 2) (Gerczak 2019) was followed when conducting these tests. Prior to loading the particles for exposure, the alumina components were subjected to a bake out run at $1600^{\circ} \mathrm{C}$ for $100 \mathrm{~h}$ to drive out asfabricated impurities from the system which may influence oxidation behavior (Opila 1995). The irradiated and unirradiated particles were loaded into a $\mathrm{SiC}$ cup and kept separate by a partition. The $\mathrm{SiC}$ cup was placed into an alumina crucible, which was then loaded into a closed-end alumina tube. The assembly and furnace are shown in Figure 2 . The furnace was evacuated under vacuum, brought to $250^{\circ} \mathrm{C}$ at $5^{\circ} \mathrm{C} / \mathrm{min}$, and held at that temperature for two hours. After the dwell, the furnace was ramped at $5^{\circ} \mathrm{C} / \mathrm{min}$ to $1400^{\circ} \mathrm{C}$. Once at temperature, flow gas from compressed gas cylinders was dispersed in the alumina housing approximately one inch above the $\mathrm{SiC}$ cup at a rate of $50 \mathrm{~mL} / \mathrm{min}$ (total internal volume of system was $\sim 321 \mathrm{~mL}$ ). Upon completion of the planned time at temperature, the flow gas was turned off, and the furnace was ramped down at $1^{\circ} \mathrm{C} / \mathrm{min}$ to room temperature.
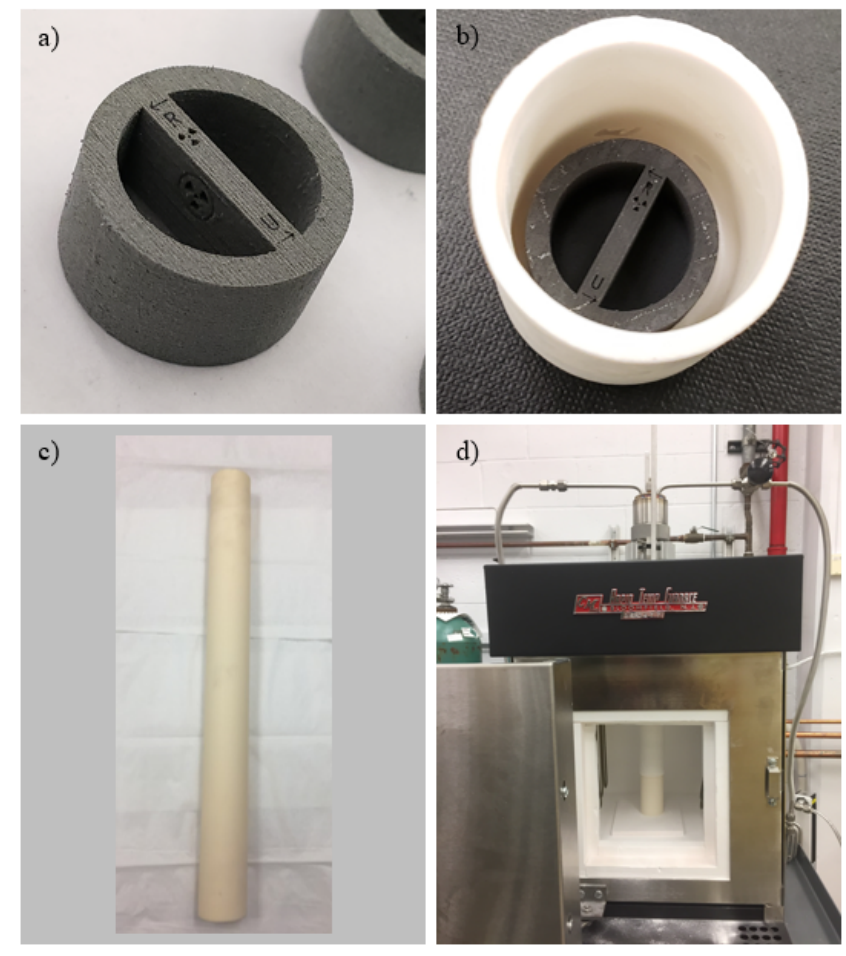

Figure 2. FITT Furnace assembly: (a) 3D printed $\mathrm{SiC}$ cup, (b) alumina holder for $\mathrm{SiC}$ cup, (c) closed-end alumina tube for housing alumina holder, and (d) FITT with door ajar showing alumina tube position.

After each test was completed, contamination levels inside the furnace and aluminum tube were first measured to determine the necessary safety protocols for handling and unloading. When readings were below a threshold designated by the facility's radiological control technicians, the $\mathrm{SiC}$ cup was removed while in the fume hood where the furnace is housed. This procedure allowed the separation between irradiated and unirradiated particles to be maintained. When contamination levels exceeded that threshold, the alumina tube was kept sealed with its end cap and was transferred to a glovebox where disassembly 
could occur. Disassembly of the $50 \mathrm{~h}$ test was performed in the fume hood, whereas the $100 \mathrm{~h}, 200 \mathrm{~h}$, and $400 \mathrm{~h}$ tests' particles were recovered in the glovebox. Glovebox disassembly was not originally anticipated during the experimental design but was later required by the radiological control technicians. Because of the glovebox dimensions, it was not practical to maintain identity between the irradiated and unirradiated particles; the tube was too tall to remove the $\mathrm{SiC}$ cup with the tube in the upright position. After either particle recovery method, the particles and $\mathrm{SiC}$ cup were transferred to the IMGA cell for visual inspection and IMGA analysis. Glovebox disassembly only caused temporary loss of identity between the two kinds of particles since IMGA analysis could identify irradiated particles based on the gamma-emitting fission products present.

\subsection{IMGA METHODS}

IMGA analysis serves to measure gamma-emitting fission product activities in individual particles, and details on its data collection methods can be found in the literature (Hunn et al. 2013). The IMGA system operates in two modes: batch mode and vial mode. In batch mode, particles are scanned on the timescale of minutes and are sorted into bins, which do not maintain individual particle identity (high throughput, short count time). In vial mode, individual particles are scanned in separate vials on the timescale of hours (low throughput, long count time). Vial mode scanning allows for measuring the lower activity fission products - such as ${ }^{154} \mathrm{Eu},{ }^{125} \mathrm{Sb}$, and ${ }^{110 \mathrm{~m}} \mathrm{Ag}$ - or higher activity fission products that have undergone numerous half-lives since the end of irradiation such that they are present in reduced number. The activities (decay corrected to one day after the end of irradiation [EOI]) are normalized to measured versus calculated $(\mathrm{M} / \mathrm{C})$ values to provide information on the release behavior of the particle. The M/C values also account for variations in kernel size, which contribute to differences in measured activities not related to release. In the interest of determining individual particle failure from an oxidation test, Eq. (3) was used to calculate the ratio of measured activity of ${ }^{137} \mathrm{Cs}$ in each particle $\mathrm{i}, \mathrm{A}_{\mathrm{i}}\left({ }^{137} \mathrm{Cs}\right.$ ), (well retained by an intact $\mathrm{SiC}$ layer) vs. the calculated average particle activity for ${ }^{137} \mathrm{Cs}, \mathrm{A}_{\text {calc }}\left({ }^{137} \mathrm{Cs}\right)$, relative to the normalized ${ }^{144} \mathrm{Ce}$ activity in particle $\mathrm{i}, \mathrm{A}_{\mathrm{i}}\left({ }^{144} \mathrm{Ce}\right.$ ) (Hunn et al. 2013).

$$
\frac{\mathrm{A}_{\mathrm{i}}\left({ }^{137} \mathrm{Cs}\right)}{\mathrm{A}_{\text {calc }}\left({ }^{137} \mathrm{Cs}\right) \frac{\mathrm{A}_{\mathrm{i}}\left({ }^{144} \mathrm{Ce}\right)}{\sum_{\mathrm{j}=1}^{\mathrm{n}}\left(\frac{1}{\mathrm{n}}\right) \mathrm{A}_{\mathrm{j}}\left({ }^{144} \mathrm{Ce}\right)}} .
$$

This same ${ }^{137} \mathrm{Cs} \mathrm{M} / \mathrm{C}$ value was previously calculated for each particle $i$ of $n$ particles recovered from Compact 5-4-2 after deconsolidation; the results are plotted in a histogram illustrating the distribution of the measured $\mathrm{Cs} \mathrm{M} / \mathrm{C}$ ratios in the as-irradiated particles from Compact 5-4-2 (Figure 3). Low retention particles, of which there were none identified from Compact 5-4-2, are typically identified as falling outside the main distribution of measured $\mathrm{M} / \mathrm{C}$ values (Hunn et al. 2018). The ${ }^{137} \mathrm{Cs} \mathrm{M} / \mathrm{C}$ values of oxidation-tested particles were compared to the ${ }^{137} \mathrm{Cs} \mathrm{M} / \mathrm{C}$ distribution of Compact 5-4-2. Any particles found with low $\mathrm{Cs}$ retention were of interest because that would imply that the SiC oxidation led to failure and subsequent fission product release during testing. From each test, six particles were selected for examination with a scanning electron microscope (SEM) equipped with a focused ion beam (FIB): three irradiated particles with no indication of fission product release and three unirradiated particles. 


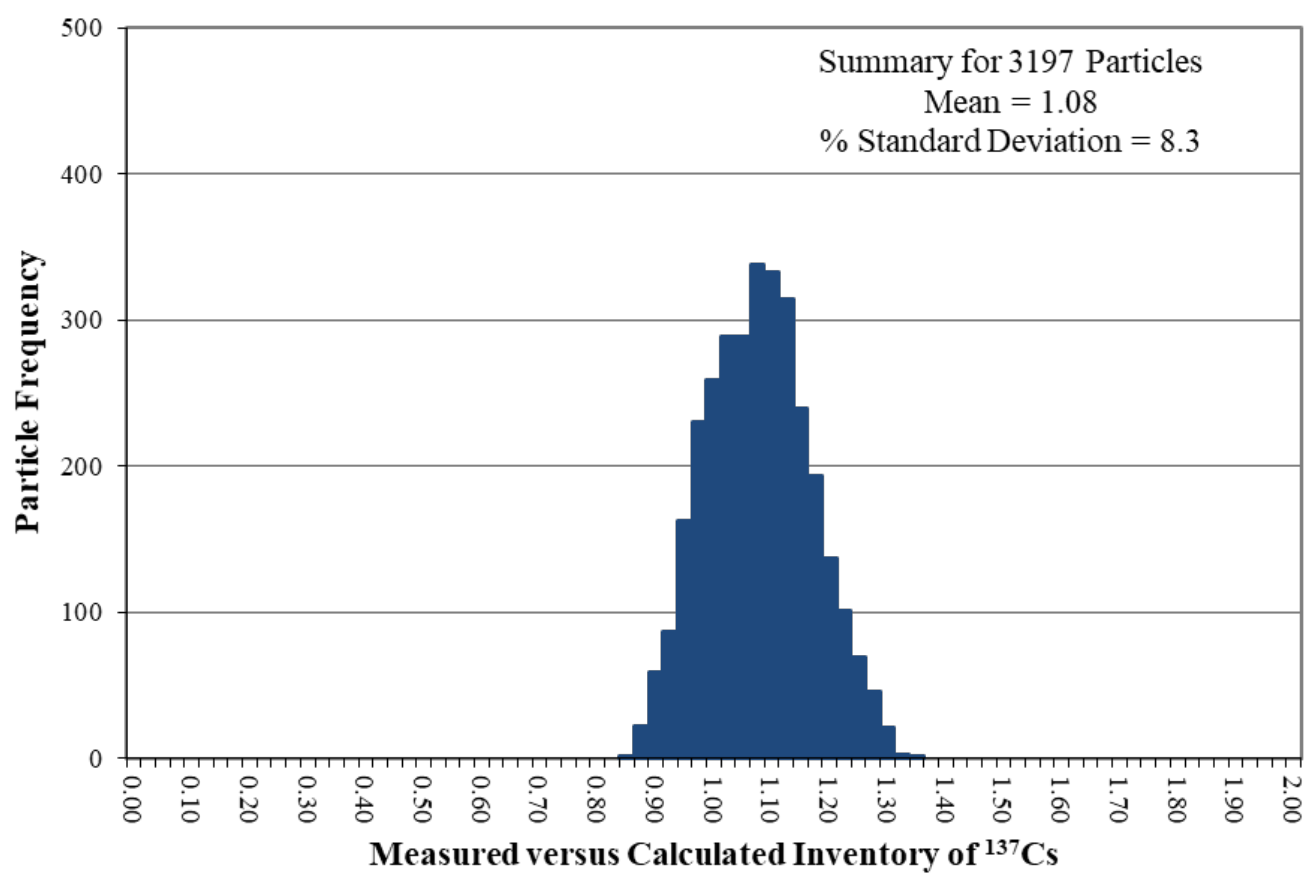

Figure 3. ${ }^{137} \mathrm{Cs} \mathrm{M} / \mathrm{C}$ histogram of Compact 5-4-2 (Hunn et al. 2018).

\subsection{SEM/FIB METHODS}

To examine oxide thickness, randomly selected particles from each FITT experiment that did not display low ${ }^{137} \mathrm{Cs} \mathrm{M} / \mathrm{C}$ values were mounted onto carbon tape on an aluminum sample stub, as shown in Figure 4, and examined using FIB milling and SEM. A ThermoFisher Scios 2 DualBeam FIB-SEM system was used for these experiments. In each sample, three $30 \mu \mathrm{m}$ wide trenches were created by milling out material using a $15 \mathrm{nA}, 30 \mathrm{kV}$ ion beam. The trenches were all approximately $15-20 \mu \mathrm{m}$ deep to capture the oxide layer. SEM images were then taken of the exposed SiC-oxide interfaces and tilt corrected to remove artifacts from image projection. In addition to these trenches, transmission electron microscope (TEM) liftouts from targeted regions in select samples (unirradiated, irradiated, and varying exposure times) were collected.

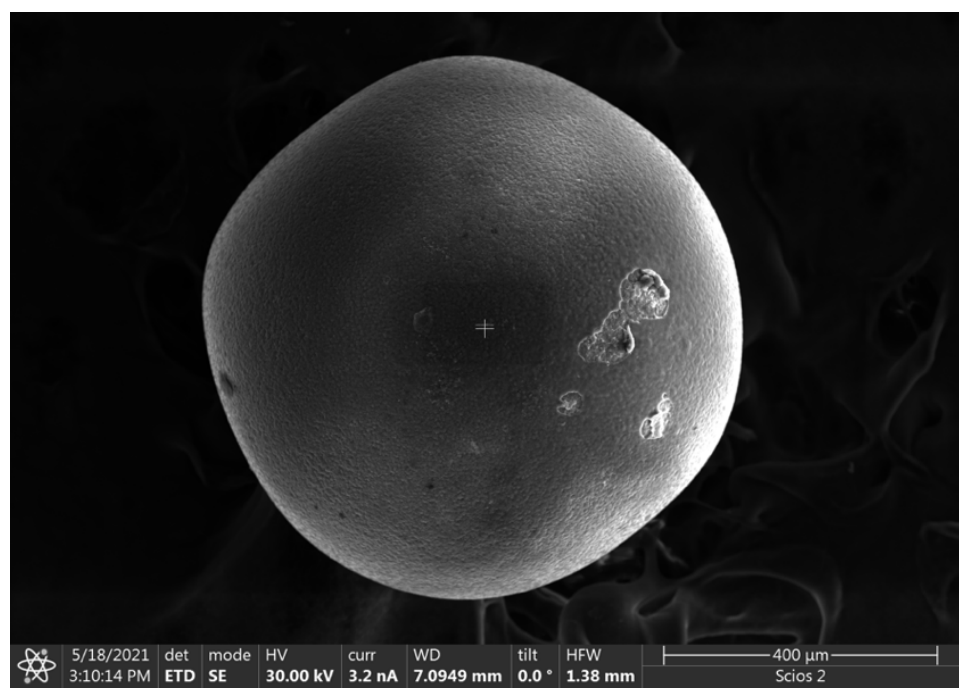

Figure 4. Example FITT particle on carbon tape for FIB/SEM analysis. 
Once collected, the images were processed using a custom MATLAB code. The code provides a userassisted drawing tool to trace the oxide layer, adjusts image rotation angle, and then calculates the thickness of the oxide from the chosen region. This program outputs hundreds to thousands of measurements compared to by-hand measurements, which only provided approximately 50 per image. Figure 5 shows an example of an oxide region identified by the user-assisted drawing tool to define the exposed oxide surface. Although the results using both methods were similar, the MATLAB code was significantly faster and provided better statistics and a more refined value for the oxide thickness. A possible artifact from the analysis of spherical particles is that slight offset from $0^{\circ}$ tilt may be imparted on how and where the milled cross-section was made. This offset would slightly influence the measured thickness of the oxide layer, based on the projection of the thickness relative to the orientation of the election beam. The thickness would be underestimated based on the cosine of the misorientation, but it would be minimal as a five-degree misorientation would result in a $0.4 \%$ reduction in measured thickness. This artifact would be present for all particles analyzed.

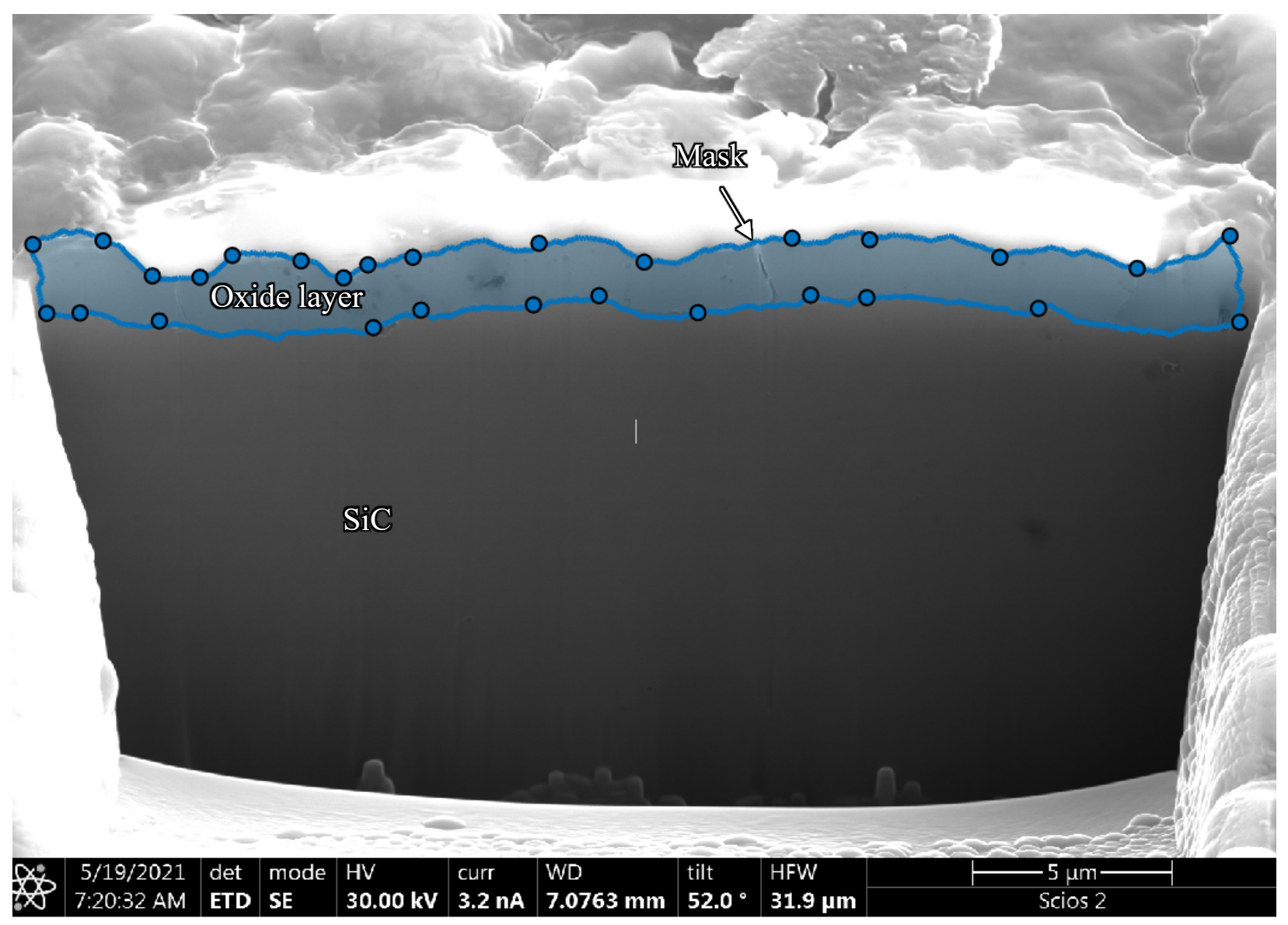

Figure 5. Example of mask applied over oxide layer to support automated thickness measurements. 


\section{RESULTS}

\subsection{IMGA RESULTS}

For the $50 \mathrm{~h}$ test, each recovered irradiated particle was assigned an ID and was gamma scanned for two hours. In the case of the $100 \mathrm{~h}, 200 \mathrm{~h}$, and $400 \mathrm{~h}$ tests - in which separation between irradiated and unirradiated particles was not maintained - all recovered particles were gamma scanned. It was apparent in the IMGA data which particles were irradiated since the values of their isotopic inventories were similar to those of an average particle in Compact 5-4-2. Average isotopic inventories of randomly selected particles from Compact 5-4-2 were previously reported (Hunn et al. 2018) and are presented in Table 5.

Table 5. Results of measured activity of 44 randomly selected particles from Compact 5-4-2 (Hunn et al. 2018)

\begin{tabular}{ccccccc}
\hline & ${ }^{106} \mathbf{R u}$ & ${ }^{125} \mathbf{S b}$ & ${ }^{134} \mathbf{C s}$ & ${ }^{137} \mathbf{C s}$ & ${ }^{144} \mathbf{C e}$ & ${ }^{154} \mathbf{E u}$ \\
\hline Maximum & $1.84 \mathrm{E}+07$ & $3.05 \mathrm{E}+05$ & $6.86 \mathrm{E}+06$ & $6.37 \mathrm{E}+06$ & $6.08 \mathrm{E}+07$ & $2.31 \mathrm{E}+05$ \\
Minimum & $1.28 \mathrm{E}+07$ & $2.24 \mathrm{E}+05$ & $4.58 \mathrm{E}+06$ & $4.71 \mathrm{E}+06$ & $4.10 \mathrm{E}+07$ & $1.48 \mathrm{E}+05$ \\
Mean & $1.57 \mathrm{E}+07$ & $2.69 \mathrm{E}+05$ & $5.43 \mathrm{E}+06$ & $5.41 \mathrm{E}+06$ & $5.11 \mathrm{E}+07$ & $1.76 \mathrm{E}+05$ \\
\% Std Dev & 8.25 & 7.17 & 9.78 & 7.21 & 7.91 & 11.20 \\
\hline
\end{tabular}

Note: Values are reported in $\mathrm{Bq}$ decay-corrected to one day after EOI.

Unirradiated particles were differentiable from irradiated particles that experienced fission product release. Previous AGR-2 PIE indicated that even when the SiC layer failed and cesium was released, certain isotopes were well retained by the kernel and pyrolytic carbon, such as ${ }^{144} \mathrm{Ce}$ and ${ }^{106} \mathrm{Ru}$ (Hunn et al. 2019). In the case of unirradiated particles after oxidation testing, the measured ${ }^{144} \mathrm{Ce}$ and ${ }^{106} \mathrm{Ru}$ activities were two to three orders of magnitude lower than that of average irradiated particles from Compact 5-4-2, indicating that they were indeed unirradiated particles and not particles with SiC failure. Any activity measured when gamma counting unirradiated particles with IMGA were caused by various sources of residual background noise that were subtracted from gamma peak data. However, since background was not constant, a net zero gamma peak for each scan was not feasible.

The measured activities of recovered irradiated particles from the $50 \mathrm{~h}$ test are given in Table 6 , and the measured activities of all recovered particles from the $100 \mathrm{~h}, 200 \mathrm{~h}$, and $400 \mathrm{~h}$ tests are listed in Table 7Table 9, respectively. There were no particle failures in the $50 \mathrm{~h}$ exposure test. Complete particle failure occurred in the $100 \mathrm{~h}, 200 \mathrm{~h}$, and $400 \mathrm{~h}$ exposure tests; complete loss of the particle was observed and no ability to recover or clearly identify failed particles was present after testing. One recovered particle was lost during examination of the $100 \mathrm{~h}$ test before it could be determined which particle type (irradiated or unirradiated) it was. 
Table 6. Measured activity of 10 irradiated particles from the $50 \mathrm{~h}$ oxidation test

\begin{tabular}{|c|c|c|c|c|c|c|c|}
\hline Particle & ${ }^{106} \mathbf{R u}$ & ${ }^{125} \mathrm{Sb}$ & ${ }^{134} \mathrm{Cs}$ & ${ }^{137} \mathrm{Cs}$ & ${ }^{144} \mathrm{Ce}$ & ${ }^{154} \mathbf{E u}$ & ${ }^{137} \mathrm{Cs} \mathrm{M} / \mathrm{C}$ \\
\hline F50-01 & $1.64 \mathrm{E}+07$ & $2.56 \mathrm{E}+05$ & $5.63 \mathrm{E}+06$ & $5.40 \mathrm{E}+06$ & $6.13 \mathrm{E}+07$ & $1.72 \mathrm{E}+05$ & 0.98 \\
\hline F50-02 & $1.42 \mathrm{E}+07$ & $2.85 E+05$ & $5.13 E+06$ & $4.98 \mathrm{E}+06$ & $5.01 E+07$ & $1.56 \mathrm{E}+05$ & 1.11 \\
\hline F50-03 & $1.31 \mathrm{E}+07$ & $2.00 \mathrm{E}+05$ & $4.60 \mathrm{E}+06$ & $4.64 \mathrm{E}+06$ & $5.86 \mathrm{E}+07$ & $1.37 \mathrm{E}+05$ & 0.88 \\
\hline F50-04 & $1.53 \mathrm{E}+07$ & $2.90 \mathrm{E}+05$ & $5.84 \mathrm{E}+06$ & $5.68 \mathrm{E}+06$ & $5.93 \mathrm{E}+07$ & $1.80 \mathrm{E}+05$ & 1.07 \\
\hline F50-05 & $1.46 \mathrm{E}+07$ & $2.93 \mathrm{E}+05$ & $5.68 \mathrm{E}+06$ & $5.59 \mathrm{E}+06$ & $5.03 \mathrm{E}+07$ & $1.78 \mathrm{E}+05$ & 1.24 \\
\hline F50-06 & $1.46 \mathrm{E}+07$ & $2.69 \mathrm{E}+05$ & $5.64 \mathrm{E}+06$ & $5.51 \mathrm{E}+06$ & $5.93 \mathrm{E}+07$ & $1.76 \mathrm{E}+05$ & 1.04 \\
\hline F50-07 & $1.42 \mathrm{E}+07$ & $2.67 \mathrm{E}+05$ & $4.63 \mathrm{E}+06$ & $4.79 E+06$ & $6.13 \mathrm{E}+07$ & $1.37 \mathrm{E}+05$ & 0.87 \\
\hline F50-08 & $1.50 \mathrm{E}+07$ & $2.41 \mathrm{E}+05$ & $5.22 \mathrm{E}+06$ & $5.12 \mathrm{E}+06$ & $5.45 \mathrm{E}+07$ & $1.64 \mathrm{E}+05$ & 1.05 \\
\hline F50-09 & $1.53 E+07$ & $2.51 \mathrm{E}+05$ & $5.41 \mathrm{E}+06$ & $5.18 E+06$ & $5.48 \mathrm{E}+07$ & $1.68 E+05$ & 1.05 \\
\hline F50-10 & 1.58E+07 & $2.79 E+05$ & $5.55 E+06$ & $5.46 \mathrm{E}+06$ & $6.09 E+07$ & $1.70 \mathrm{E}+05$ & 1.00 \\
\hline
\end{tabular}

Note: Activities are reported in $\mathrm{Bq}$ decay-corrected to one day after EOI. Irradiated particles selected for SEM/FIB examination are in bold.

Table 7. Measured activity of 15 particles recovered from the $100 \mathrm{~h}$ oxidation test

\begin{tabular}{|c|c|c|c|c|c|c|c|}
\hline Particle & ${ }^{106} \mathrm{Ru}$ & ${ }^{125} \mathrm{Sb}$ & ${ }^{134} \mathrm{Cs}$ & ${ }^{137} \mathrm{Cs}$ & ${ }^{144} \mathrm{Ce}$ & ${ }^{154} \mathbf{E u}$ & ${ }^{137} \mathrm{Cs} \mathrm{M} / \mathrm{C}$ \\
\hline F100-01 & $9.45 \mathrm{E}+04$ & $1.18 \mathrm{E}+04$ & $5.30 \mathrm{E}+04$ & $8.12 \mathrm{E}+04$ & $0.00 \mathrm{E}+00$ & $0.00 \mathrm{E}+00$ & N/A \\
\hline F100-02 & $1.56 \mathrm{E}+07$ & $2.76 \mathrm{E}+05$ & $5.21 \mathrm{E}+06$ & $5.26 \mathrm{E}+06$ & $5.58 \mathrm{E}+07$ & $1.66 \mathrm{E}+05$ & 1.05 \\
\hline F100-03 & $2.01 \mathrm{E}+05$ & $7.30 \mathrm{E}+03$ & $8.00 \mathrm{E}+04$ & $1.20 \mathrm{E}+05$ & $0.00 \mathrm{E}+00$ & $0.00 \mathrm{E}+00$ & N/A \\
\hline F100-04 & $1.59 \mathrm{E}+07$ & $2.70 \mathrm{E}+05$ & $5.21 \mathrm{E}+06$ & $5.52 \mathrm{E}+06$ & $6.41 \mathrm{E}+07$ & $1.76 \mathrm{E}+05$ & 0.96 \\
\hline F100-05 & $1.56 \mathrm{E}+07$ & $2.17 \mathrm{E}+05$ & $4.40 \mathrm{E}+06$ & $4.71 \mathrm{E}+06$ & $6.01 \mathrm{E}+07$ & $1.51 \mathrm{E}+05$ & 0.87 \\
\hline F100-06 & $0.00 \mathrm{E}+00$ & $0.00 \mathrm{E}+00$ & $5.27 \mathrm{E}+04$ & $8.59 \mathrm{E}+04$ & $0.00 \mathrm{E}+00$ & $0.00 \mathrm{E}+00$ & N/A \\
\hline F100-07 & $1.22 \mathrm{E}+05$ & $1.15 \mathrm{E}+04$ & $4.43 \mathrm{E}+04$ & $7.75 \mathrm{E}+04$ & $0.00 \mathrm{E}+00$ & $0.00 \mathrm{E}+00$ & N/A \\
\hline F100-08 & $1.22 \mathrm{E}+07$ & $2.30 \mathrm{E}+05$ & $5.24 \mathrm{E}+06$ & $5.30 \mathrm{E}+06$ & $5.84 E+07$ & $1.72 \mathrm{E}+05$ & 1.01 \\
\hline F100-09 & $1.24 E+07$ & $2.22 \mathrm{E}+05$ & $4.98 E+06$ & $5.17 E+06$ & $5.79 E+07$ & $1.63 E+05$ & 1.00 \\
\hline F100-10 & $1.44 E+07$ & $2.59 \mathrm{E}+05$ & $4.99 \mathrm{E}+06$ & $5.16 \mathrm{E}+06$ & $6.08 E+07$ & $1.56 \mathrm{E}+05$ & 0.95 \\
\hline F100-11 & $1.47 \mathrm{E}+07$ & $2.39 \mathrm{E}+05$ & $5.19 \mathrm{E}+06$ & $5.19 \mathrm{E}+06$ & $4.95 \mathrm{E}+07$ & $1.72 \mathrm{E}+05$ & 1.17 \\
\hline F100-12 & $6.56 \mathrm{E}+05$ & $0.00 \mathrm{E}+00$ & $5.68 \mathrm{E}+04$ & $7.85 \mathrm{E}+04$ & $0.00 \mathrm{E}+00$ & $0.00 \mathrm{E}+00$ & N/A \\
\hline F100-13 & $7.73 \mathrm{E}+05$ & $-1.58 \mathrm{E}+03$ & $5.27 \mathrm{E}+04$ & $7.62 \mathrm{E}+04$ & $0.00 \mathrm{E}+00$ & $0.00 \mathrm{E}+00$ & N/A \\
\hline F100-14 & $1.29 \mathrm{E}+07$ & $2.54 \mathrm{E}+05$ & $4.65 \mathrm{E}+06$ & $4.78 \mathrm{E}+06$ & $6.45 \mathrm{E}+07$ & $1.48 \mathrm{E}+05$ & 0.83 \\
\hline F100-15 & $8.22 \mathrm{E}+04$ & $0.00 \mathrm{E}+00$ & $5.02 \mathrm{E}+04$ & $7.41 \mathrm{E}+04$ & $0.00 \mathrm{E}+00$ & $0.00 \mathrm{E}+00$ & N/A \\
\hline
\end{tabular}

Note: Activities are reported in $\mathrm{Bq}$ decay-corrected to one day after EOI.

Irradiated particles are shaded in gray, and irradiated particles selected for SEM/FIB examination are in bold. 
Table 8. Measured activity of 18 particles recovered from the $200 \mathrm{~h}$ oxidation test

\begin{tabular}{|c|c|c|c|c|c|c|c|}
\hline Particle & ${ }^{106} \mathrm{Ru}$ & ${ }^{125} \mathrm{Sb}$ & ${ }^{134} \mathrm{Cs}$ & ${ }^{137} \mathrm{Cs}$ & ${ }^{144} \mathrm{Ce}$ & ${ }^{154} \mathbf{E u}$ & ${ }^{137} \mathrm{Cs} \mathrm{M} / \mathrm{C}$ \\
\hline F200-01 & $1.66 E+07$ & $2.62 E+05$ & $5.50 \mathrm{E}+06$ & $5.76 \mathrm{E}+06$ & $6.03 E+07$ & $1.94 E+05$ & 1.06 \\
\hline F200-02 & $0.00 \mathrm{E}+00$ & $0.00 \mathrm{E}+00$ & $8.09 \mathrm{E}+04$ & $1.49 \mathrm{E}+05$ & $0.00 \mathrm{E}+00$ & $1.89 \mathrm{E}+04$ & N/A \\
\hline F200-03 & $2.56 \mathrm{E}+05$ & $0.00 \mathrm{E}+00$ & $6.42 \mathrm{E}+04$ & $1.39 \mathrm{E}+05$ & $0.00 \mathrm{E}+00$ & $1.97 \mathrm{E}+04$ & N/A \\
\hline F200-04 & $1.47 \mathrm{E}+07$ & $2.88 \mathrm{E}+05$ & $5.35 \mathrm{E}+06$ & $5.66 \mathrm{E}+06$ & $5.96 \mathrm{E}+07$ & $1.93 \mathrm{E}+05$ & 1.06 \\
\hline F200-05 & $1.60 \mathrm{E}+07$ & $2.87 E+05$ & $5.94 E+06$ & $5.84 \mathrm{E}+06$ & $6.17 E+07$ & $2.06 \mathrm{E}+05$ & 1.05 \\
\hline F200-06 & $9.56 \mathrm{E}+04$ & $0.00 \mathrm{E}+00$ & $1.33 \mathrm{E}+05$ & $2.19 \mathrm{E}+05$ & $0.00 \mathrm{E}+00$ & $2.06 \mathrm{E}+04$ & N/A \\
\hline F200-07 & $1.47 E+07$ & $2.56 \mathrm{E}+05$ & $5.67 E+06$ & $5.62 E+06$ & $5.39 \mathrm{E}+07$ & $1.97 E+05$ & 1.16 \\
\hline F200-08 & $9.10 \mathrm{E}+04$ & $0.00 \mathrm{E}+00$ & $1.15 \mathrm{E}+05$ & $2.18 \mathrm{E}+05$ & $0.00 \mathrm{E}+00$ & $2.52 \mathrm{E}+04$ & N/A \\
\hline F200-09 & $1.41 \mathrm{E}+07$ & $2.54 \mathrm{E}+05$ & $4.75 \mathrm{E}+06$ & $5.10 \mathrm{E}+06$ & $5.96 \mathrm{E}+07$ & $1.79 \mathrm{E}+05$ & 0.95 \\
\hline F200-10 & $0.00 \mathrm{E}+00$ & $0.00 \mathrm{E}+00$ & $6.58 \mathrm{E}+04$ & $1.37 \mathrm{E}+05$ & $0.00 \mathrm{E}+00$ & $1.87 \mathrm{E}+04$ & N/A \\
\hline F200-11 & $1.76 \mathrm{E}+05$ & $0.00 \mathrm{E}+00$ & $7.69 \mathrm{E}+04$ & $1.41 \mathrm{E}+05$ & $0.00 \mathrm{E}+00$ & $1.98 \mathrm{E}+04$ & N/A \\
\hline F200-12 & $1.39 \mathrm{E}+07$ & $2.43 \mathrm{E}+05$ & $4.81 \mathrm{E}+06$ & $5.08 \mathrm{E}+06$ & $5.51 \mathrm{E}+07$ & $1.73 \mathrm{E}+05$ & 1.03 \\
\hline F200-13 & $0.00 \mathrm{E}+00$ & $0.00 \mathrm{E}+00$ & $6.17 \mathrm{E}+04$ & $1.37 \mathrm{E}+05$ & $0.00 \mathrm{E}+00$ & $2.08 \mathrm{E}+04$ & N/A \\
\hline F200-14 & $0.00 \mathrm{E}+00$ & $0.00 \mathrm{E}+00$ & $6.50 \mathrm{E}+04$ & $1.33 \mathrm{E}+05$ & $0.00 \mathrm{E}+00$ & $1.86 \mathrm{E}+04$ & N/A \\
\hline F200-15 & $1.73 \mathrm{E}+07$ & $3.00 \mathrm{E}+05$ & $6.14 \mathrm{E}+06$ & $6.02 \mathrm{E}+06$ & $6.17 \mathrm{E}+07$ & $2.15 \mathrm{E}+05$ & 1.09 \\
\hline F200-16 & $2.48 \mathrm{E}+05$ & $0.00 \mathrm{E}+00$ & $6.89 \mathrm{E}+04$ & $1.45 \mathrm{E}+05$ & $0.00 \mathrm{E}+00$ & $1.83 \mathrm{E}+04$ & N/A \\
\hline F200-17 & $1.62 \mathrm{E}+07$ & $2.18 \mathrm{E}+05$ & $5.15 \mathrm{E}+06$ & $5.28 \mathrm{E}+06$ & $5.26 \mathrm{E}+07$ & $1.86 \mathrm{E}+05$ & 1.12 \\
\hline F200-18 & $2.81 \mathrm{E}+05$ & $0.00 \mathrm{E}+00$ & $1.29 \mathrm{E}+05$ & $2.14 \mathrm{E}+05$ & $0.00 \mathrm{E}+00$ & $1.95 \mathrm{E}+04$ & N/A \\
\hline
\end{tabular}

Note: Activities are reported in Bq decay-corrected to one day after EOI.

Irradiated particles are shaded in gray, and irradiated particles selected for SEM/FIB examination are in bold.

Table 9. Measured activity of 13 particles recovered from the $400 \mathrm{~h}$ oxidation test

\begin{tabular}{|c|c|c|c|c|c|c|c|}
\hline Particle & ${ }^{106} \mathbf{R u}$ & ${ }^{125} \mathrm{Sb}$ & ${ }^{134} \mathrm{Cs}$ & ${ }^{137} \mathrm{Cs}$ & ${ }^{144} \mathrm{Ce}$ & ${ }^{154} \mathbf{E u}$ & ${ }^{137} \mathrm{Cs} \mathrm{M} / \mathrm{C}$ \\
\hline F400-01 & $1.22 \mathrm{E}+05$ & $0.00 \mathrm{E}+00$ & $1.06 \mathrm{E}+05$ & $1.67 \mathrm{E}+05$ & $0.00 \mathrm{E}+00$ & $1.53 \mathrm{E}+04$ & N/A \\
\hline F400-02 & $2.73 \mathrm{E}+05$ & $8.59 \mathrm{E}+03$ & $1.12 \mathrm{E}+05$ & $1.62 \mathrm{E}+05$ & $0.00 \mathrm{E}+00$ & $1.76 \mathrm{E}+04$ & N/A \\
\hline F400-03 & $2.18 \mathrm{E}+05$ & $1.15 \mathrm{E}+04$ & $1.10 \mathrm{E}+05$ & $1.71 \mathrm{E}+05$ & $0.00 \mathrm{E}+00$ & $1.82 \mathrm{E}+04$ & N/A \\
\hline F400-04 & $4.73 \mathrm{E}+05$ & $0.00 \mathrm{E}+00$ & $1.07 \mathrm{E}+05$ & $1.62 \mathrm{E}+05$ & $0.00 \mathrm{E}+00$ & $1.72 \mathrm{E}+04$ & N/A \\
\hline F400-05 & $2.71 \mathrm{E}+05$ & $0.00 \mathrm{E}+00$ & $1.19 \mathrm{E}+05$ & $1.90 \mathrm{E}+05$ & $0.00 \mathrm{E}+00$ & $2.32 \mathrm{E}+04$ & N/A \\
\hline F400-06 & $6.30 \mathrm{E}+05$ & $0.00 \mathrm{E}+00$ & $1.09 \mathrm{E}+05$ & $1.61 \mathrm{E}+05$ & $0.00 \mathrm{E}+00$ & $1.65 \mathrm{E}+04$ & N/A \\
\hline F400-07 & $7.10 \mathrm{E}+05$ & $0.00 \mathrm{E}+00$ & $1.03 \mathrm{E}+05$ & $1.62 \mathrm{E}+05$ & $0.00 \mathrm{E}+00$ & $1.74 \mathrm{E}+04$ & N/A \\
\hline F400-08 & $1.53 E+07$ & $2.68 E+05$ & $5.03 E+06$ & $5.40 \mathrm{E}+06$ & $6.75 E+07$ & $1.79 E+05$ & 0.89 \\
\hline F400-09 & $5.49 \mathrm{E}+05$ & $1.22 \mathrm{E}+04$ & $1.08 \mathrm{E}+05$ & $1.61 \mathrm{E}+05$ & $0.00 \mathrm{E}+00$ & $1.61 \mathrm{E}+04$ & $\mathrm{~N} / \mathrm{A}$ \\
\hline F400-10 & $1.42 \mathrm{E}+07$ & $2.95 E+05$ & $5.58 \mathrm{E}+06$ & $5.67 E+06$ & $5.42 \mathrm{E}+07$ & $1.88 E+05$ & 1.16 \\
\hline F400-11 & $1.35 \mathrm{E}+07$ & $2.59 \mathrm{E}+05$ & $5.50 \mathrm{E}+06$ & $5.55 \mathrm{E}+06$ & $5.18 \mathrm{E}+07$ & $1.86 \mathrm{E}+05$ & 1.19 \\
\hline F400-12 & $0.00 \mathrm{E}+00$ & $0.00 \mathrm{E}+00$ & $1.06 \mathrm{E}+05$ & $1.60 \mathrm{E}+05$ & $0.00 \mathrm{E}+00$ & $2.12 \mathrm{E}+04$ & N/A \\
\hline F400-13 & $1.70 \mathrm{E}+07$ & $2.83 E+05$ & $5.45 E+06$ & $5.79 E+06$ & $6.74 E+07$ & $1.85 E+05$ & 0.96 \\
\hline
\end{tabular}

Note: Activities are reported in Bq decay-corrected to one day after EOI.

Irradiated particles are shaded in gray, and irradiated particles selected for SEM/FIB examination are in bold.

Again, because cesium is well retained in intact particles, low ${ }^{137} \mathrm{Cs}$ activity is an indicator of a particle with either a full TRISO failure or SiC failure (Hunn et al. 2013). A histogram of the ${ }^{137} \mathrm{Cs} \mathrm{M} / \mathrm{C}$ ratio for the recovered irradiated particles is compared with the as-irradiated distribution in Figure 6. The IMGA 
analysis showed that no recovered particles had abnormally low ${ }^{137} \mathrm{Cs} \mathrm{M} / \mathrm{C}$, in that their retained inventory fractions were not below the distribution presented in the as-irradiated condition. This indicated that no recovered particles released enough ${ }^{137} \mathrm{Cs}$ to be detectable by the resolution of IMGA analysis, and therefore no recovered particles were detected as having failed TRISO or SiC layers.

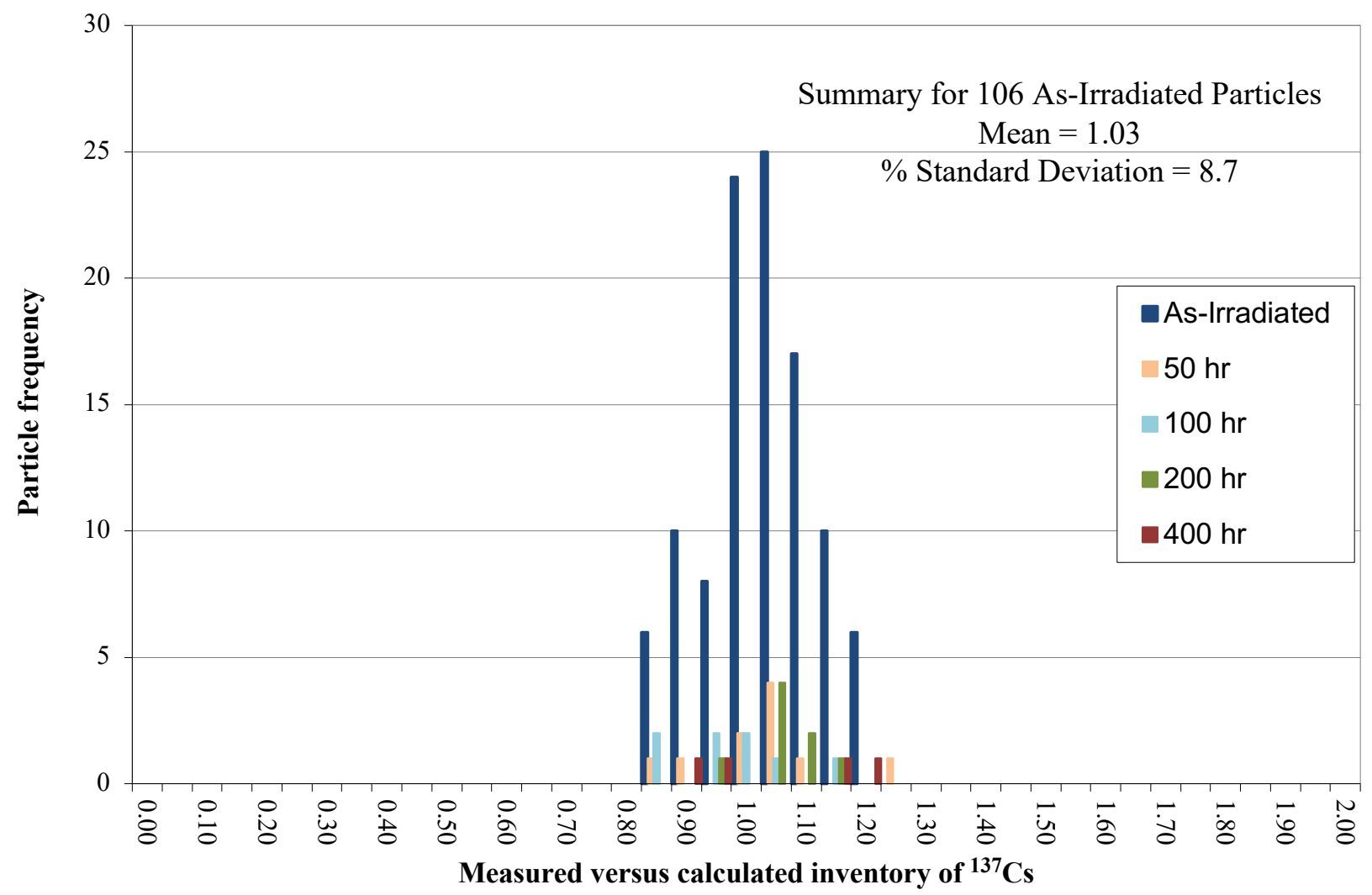

Figure 6. Measured versus calculated inventory of ${ }^{137} \mathrm{Cs}$ for as-irradiated and oxidation-tested particles.

Assuming no recovered particles were failed, based on lack of evidence of failure from IMGA survey, gross particle failure was determined by conducting a particle count during capsule disassembly. All missing particles were considered failed. The exception being the particle lost during IMGA counting from the $100 \mathrm{~h}$. The count was confirmed under stereoscope examination once transferred to the IMGA cell. Furthermore, evidence of particle failure (e.g., debris or $\mathrm{SiC}$ fragments) was only observed for the $200 \mathrm{~h}$ test, in which one fragment of a SiC coating was recovered with the surviving particles. Residual debris and $\mathrm{SiC}$ fragments from failed particles were possibly bonded to the cup and not clearly resolved by stereoscopic analysis in the IMGA cell. Enumerating the particle failures indicated that there was a correlation between oxidation exposure time and failure response for irradiated particles (Figure 7). Unirradiated particles showed failure in the $100 \mathrm{~h}$ and $400 \mathrm{~h}$ exposures. There was no clear trend in failure fraction in the unirradiated condition from $50-400 \mathrm{~h}$ with failure observed at $100 \mathrm{~h}$ and $400 \mathrm{~h}$ exposures. In Figure 7 the error bar for the $100 \mathrm{~h}$ exposure presents the potential range in failure fraction caused by the loss of one recovered particle during IMGA analysis. The unirradiated failure observations suggest that a baseline subset of particles were susceptible to failure at $100 \mathrm{~h}$ or more regardless of exposure time. Considering the irradiated particle response, the particle failures observed at $100 \mathrm{~h}$ and $200 \mathrm{~h}$ are on the order of the particle failure fractions observed in the unirradiated condition. However, at $400 \mathrm{~h}, 60 \%$ of irradiated particles were observed to fail based on the number of particles recovered during disassembly and identification of particle type with IMGA. No direct observation of the specific failure mechanism was determined. This failure fraction was above the estimated baseline identified in the 
unirradiated control particles and well above the $10 \%$ failure fraction observed for the unirradiated particles at $400 \mathrm{~h}$. This trend indicated a general increase in particle failure with increasing exposure time for irradiated burnback TRISO particles from Compact 5-4-2.

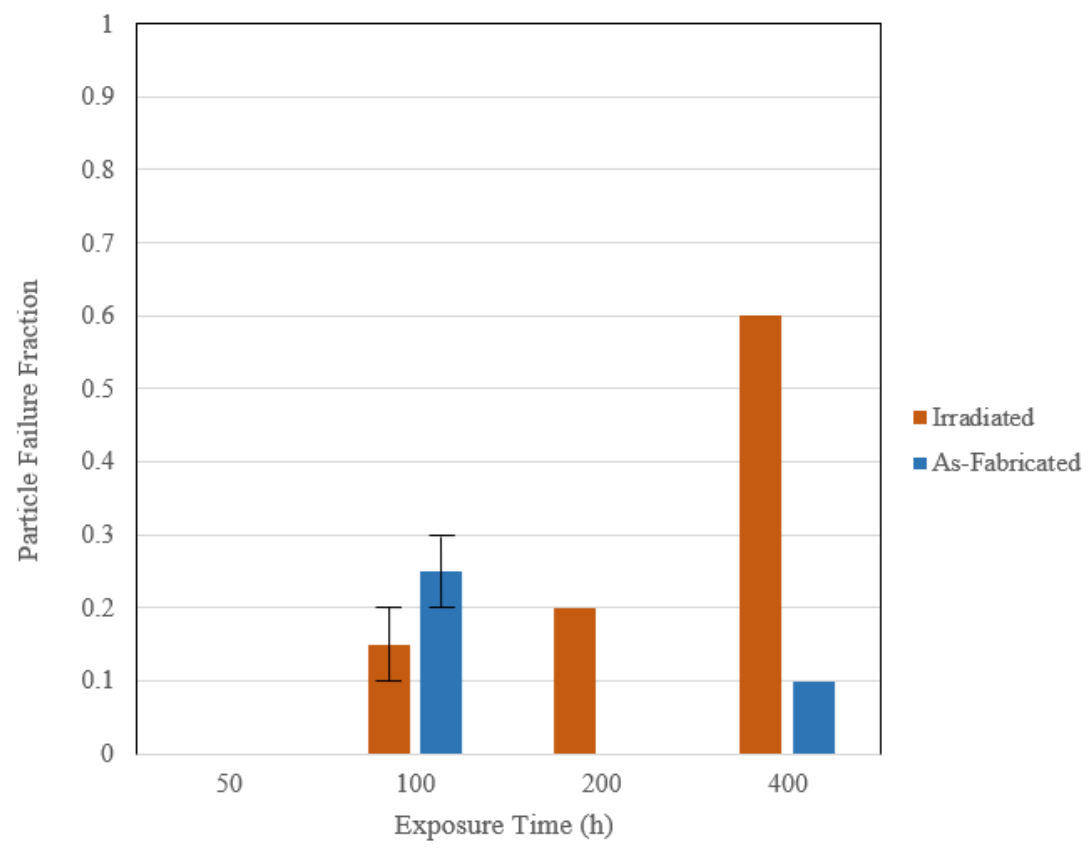

Figure 7. Particle failure fraction versus exposure time at $1400^{\circ} \mathrm{C}$.

\subsection{SEM/FIB RESULTS}

Micrographs of the oxidized surface and oxide thickness were collected from representative particles from all four FITT exposures (Table 3), covering both irradiated and unirradiated particles for comparison at each $1400^{\circ} \mathrm{C}$ exposure time. Example locations from each particle type for each test condition are presented in Figure 8-Figure 11. All particles showed a primary oxide layer adjacent to the underlying $\mathrm{SiC}$ layer. In addition to the expected oxide layer, some samples had a secondary oxide layer of different appearance that was thicker than the surface oxide, as shown in Figure 12. This secondary oxide layer was not uniform over the particle surface while the primary oxide layer was uniform around the exposed particle surface. At this reporting, it is not clear what the source of this secondary oxide layer was; however, it appeared to be associated with the contact point between the particle and the bottom of the $\mathrm{SiC}$ crucible, where the particles sat. The nonuniform secondary oxide layer was pronounced adjacent to the apparent connection points between particles and the $\mathrm{SiC}$ cup. It is plausible that co-oxidation of the $\mathrm{SiC}$ cup enabled this oxide film buildup where the particle and cup were in contact; other speculated mechanisms may be impurity content in the holder or gas, or gas delivery variation within the crucible. Due to the appearance of this secondary oxide (shown as bright regions in Figure 9 and Figure 10), and due to the curvature of the sample creating difficult FIB geometries to work with, it was sometimes unavoidable to make trenches near the secondary oxide which varied spatially. However, because three trenches were made on each sample, as discussed in Section 2.3, trenches were made as spread out as possible over the usable region of each sample. Then, the oxide layer thickness was analyzed and compared, and it was confirmed that the oxide thickness remained within reasonable deviation in the $50 \mathrm{~h}$, $100 \mathrm{~h}$, and $200 \mathrm{~h}$ exposures. For example, the trench shown in the $100 \mathrm{~h}$ unirradiated sample (Figure 9) was close to the secondary oxide region but did not show the secondary oxide in the trench, nor did it deviate from the oxide thicknesses of trenches made further away from the oxide. 
Unirradiated Sample
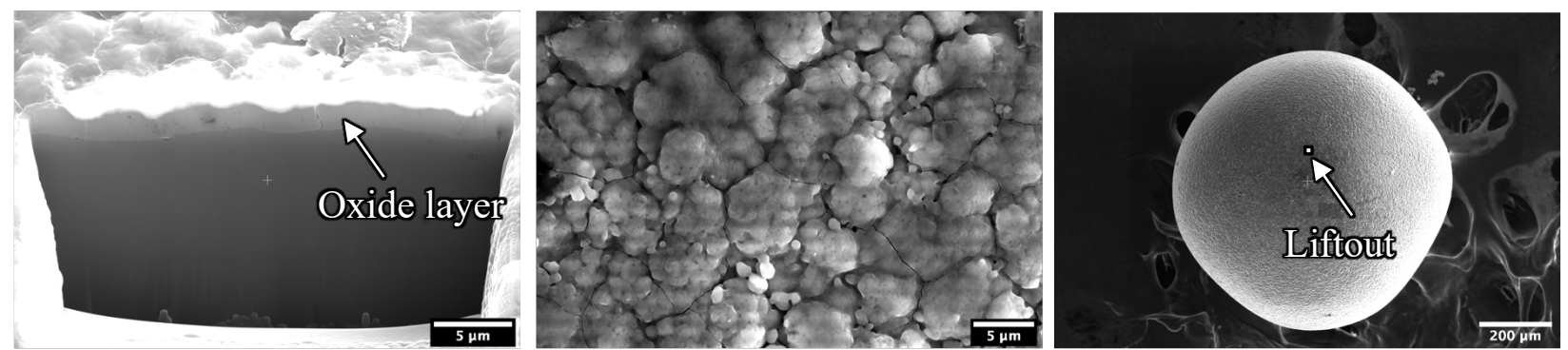

Irradiated Sample
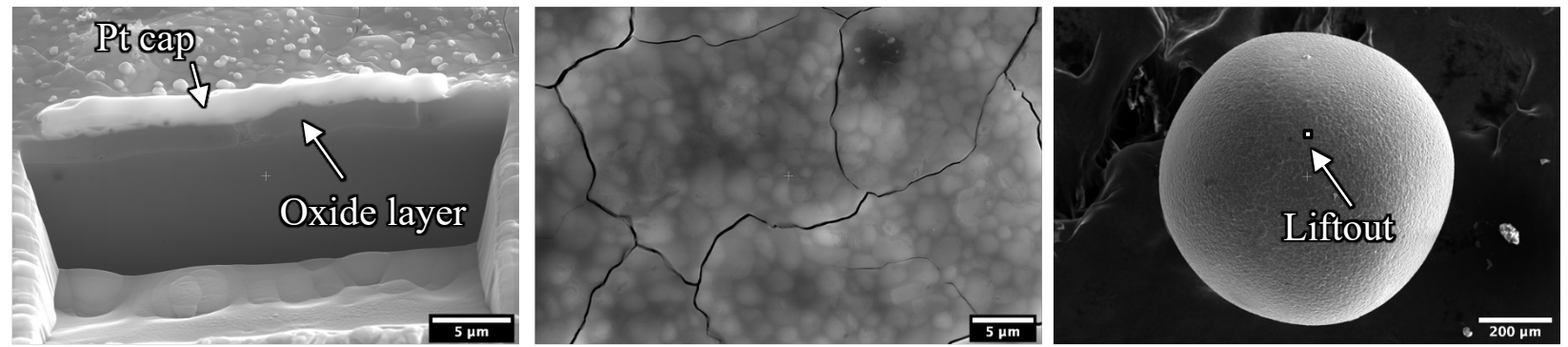

Figure 8. Cross section and surface images of the $50 \mathrm{~h}$ unirradiated and irradiated FITT samples.
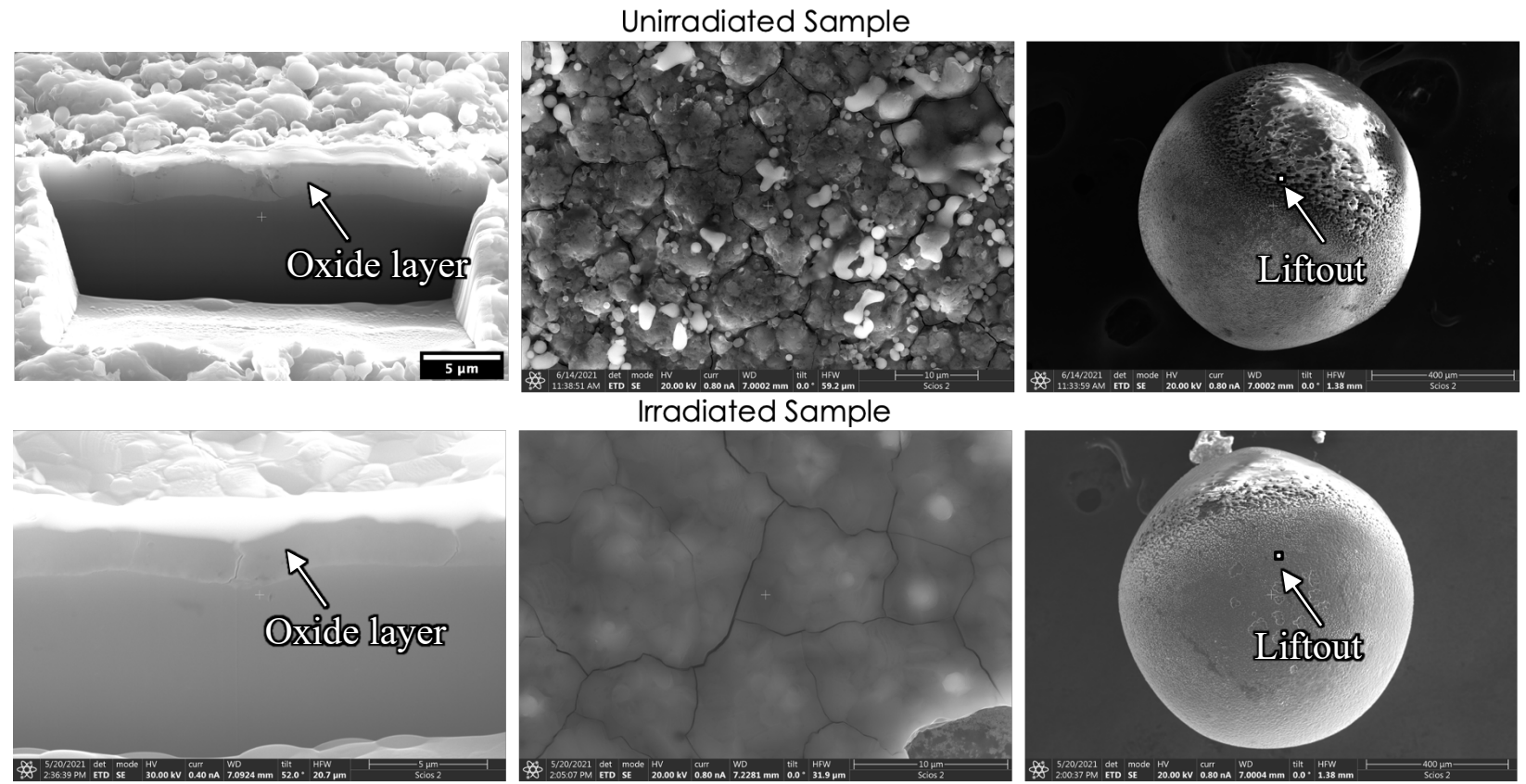

Irradiated Sample
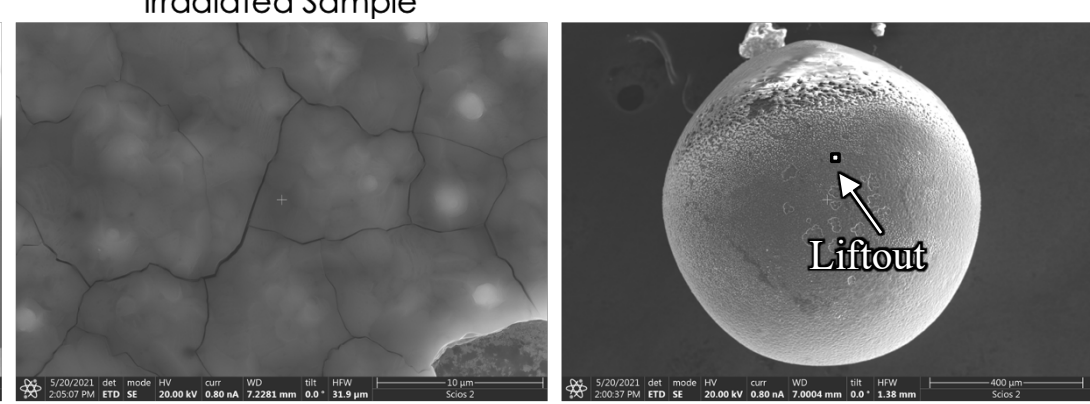

Figure 9. Cross section and surface images of the $100 \mathrm{~h}$ unirradiated and irradiated FITT samples. 

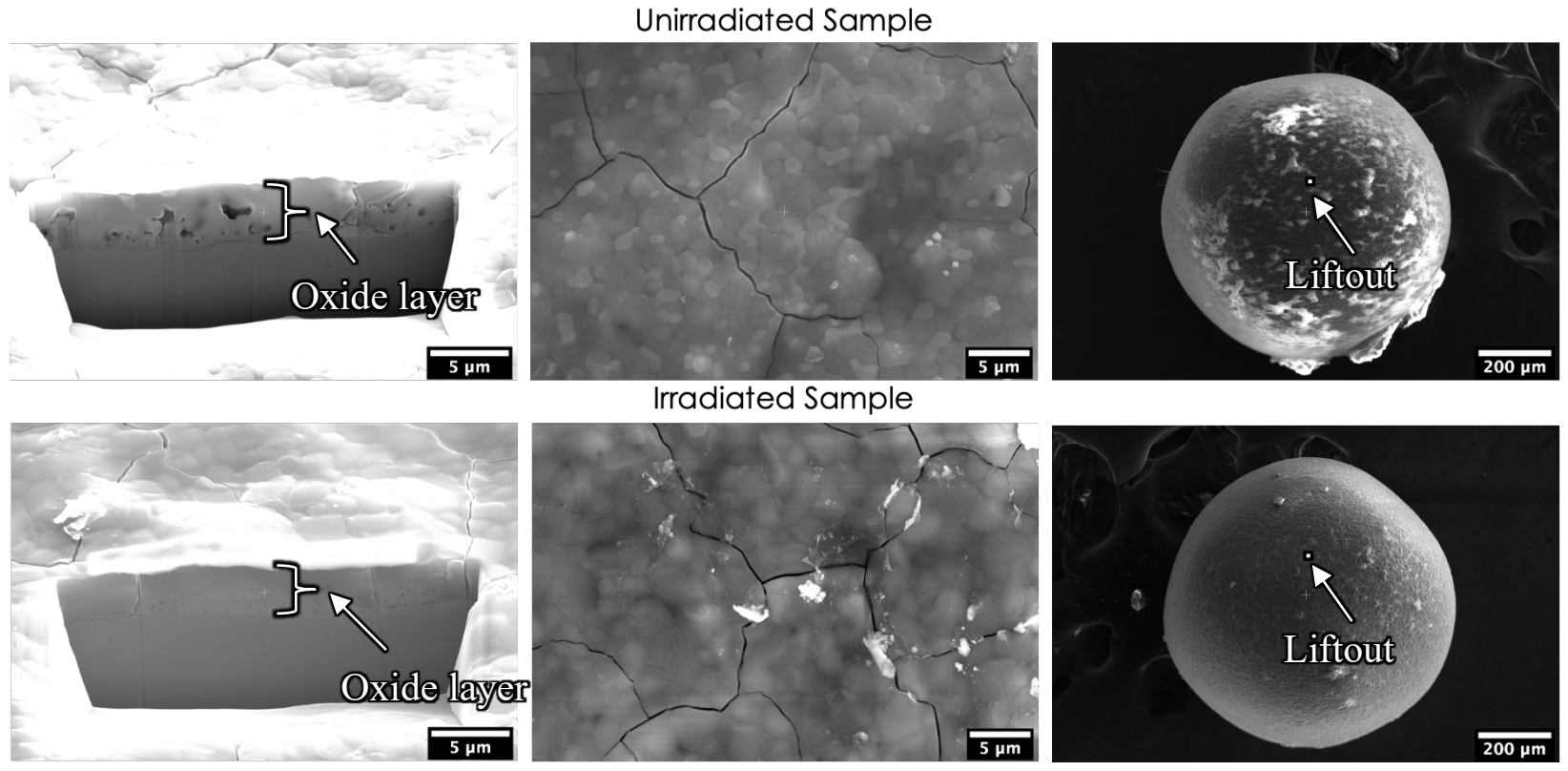

Figure 10. Cross section and surface images of the $200 \mathrm{~h}$ unirradiated and irradiated FITT samples.
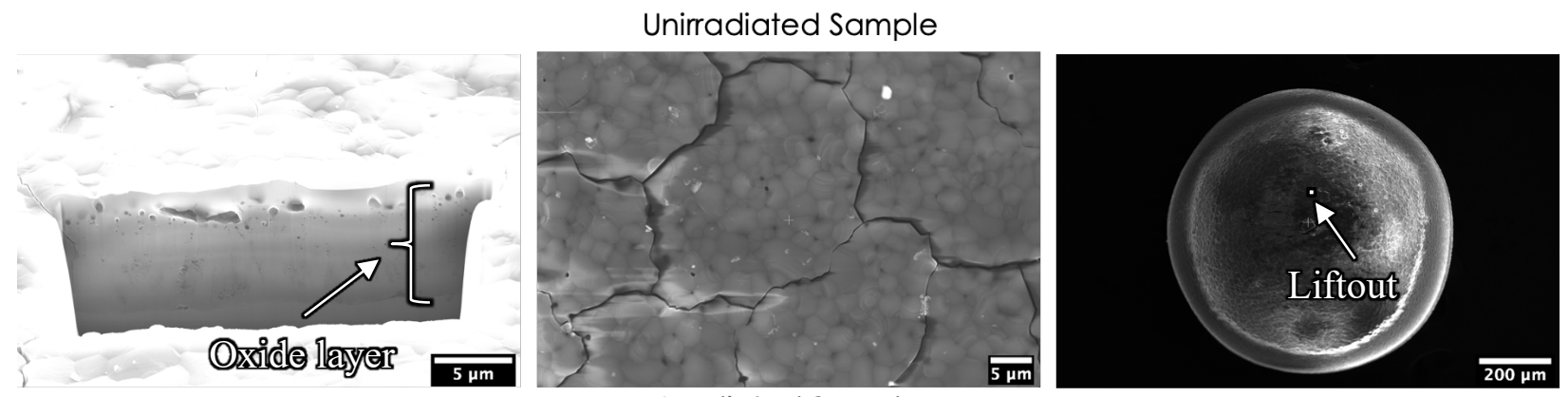

Irradiated Sample
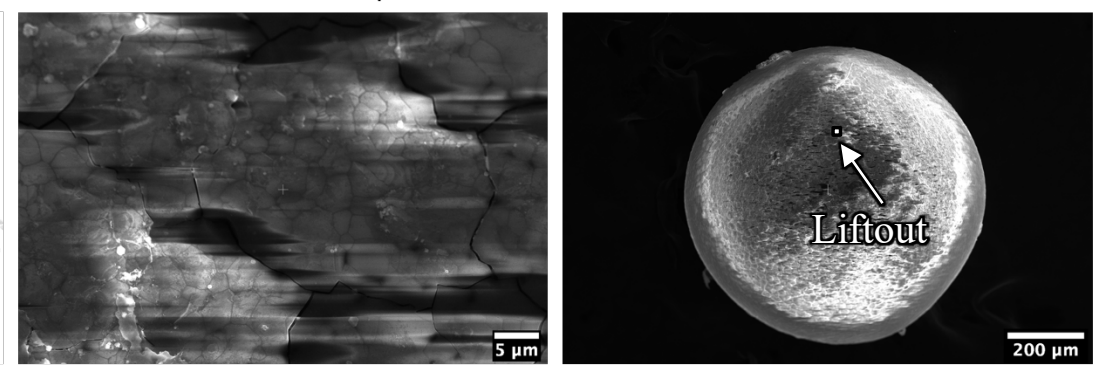

Figure 11. Cross section and surface images of the $400 \mathrm{~h}$ unirradiated and irradiated FITT samples. Charging on the irradiated sample caused blurring of the sample surface image. 

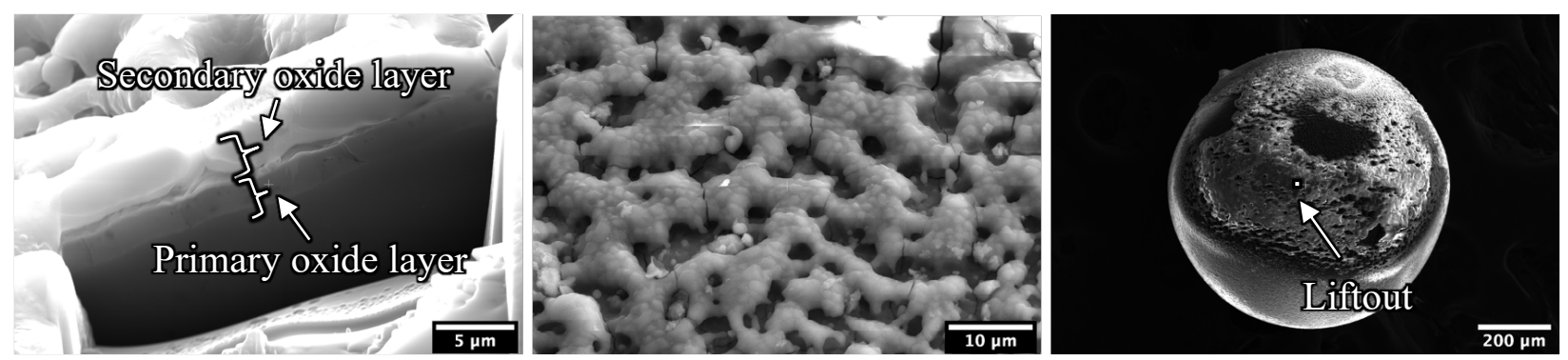

Figure 12. Example of the secondary oxide found on some of the samples from $100 \mathrm{~h}$ unirradiated condition.

An observation unique to this work was the difference in the oxide layer structure between the unirradiated and irradiated particles. The unirradiated microstructure in the $50 \mathrm{~h}$ and $100 \mathrm{~h}$ exposures showed a fine grain size and a rough topography. Comparatively, the oxide microstructures for the $50 \mathrm{~h}$ and $100 \mathrm{~h}$ irradiated particles appeared smooth and uniform, suggesting uniform oxidation of the entire exposed surface. The surfaces of all particles (unirradiated and irradiated) in the $200 \mathrm{~h}$ and $400 \mathrm{~h}$ samples appeared uniform. The observed cracking is expected upon cooling because of the difference in the coefficient of thermal expansion between $\mathrm{SiO}_{2}$ and $\mathrm{SiC}$. The cross sections also revealed information concerning open pore structure. In the longer-term exposure tests $(200 \mathrm{~h}$ and $400 \mathrm{~h})$, samples had a more pronounced presence of pores in the oxide layer relative to the shorter-term exposures $(50 \mathrm{~h}$ and $100 \mathrm{~h})$. Additionally, micrometer porosity was present in the oxide layer of the unirradiated particles after $200 \mathrm{~h}$ and in both particle types after $400 \mathrm{~h}$. The pores were more pronounced in the second half of the oxide layer in the $400 \mathrm{~h}$ exposures. Figure 13 shows a higher magnification SEM image of the $400 \mathrm{~h}$ exposure samples. In these samples, bubbles were observed from the $\mathrm{SiC}$ layer through the $\mathrm{SiO}_{2}$ layer. In Figure 13 , it is possible to see somewhat radially oriented tracks of smaller bubbles/pores extending outward from the $\mathrm{SiC}$ surface, indicated by yellow brackets. Then, above these somewhat radial channels are larger bubbles/pores, indicated by orange brackets. The smaller bubbles appear larger and denser in the irradiated sample compared to the unirradiated sample. In both samples, these small bubble tracks culminate in larger bubbles nearer to the sample surface at what appears to be a transition within oxide regions. It is possible these tracks are planes of bubbles possibly aligned with grain boundaries (or some other nucleation site) in the substrate. However, some regions of bubbles were much wider than the width of grain boundaries. TEM investigations will clarify if and where they preferentially locate. Threedimensional serial sectioning may also illuminate critical insight on the pore structure and distribution.

(a)

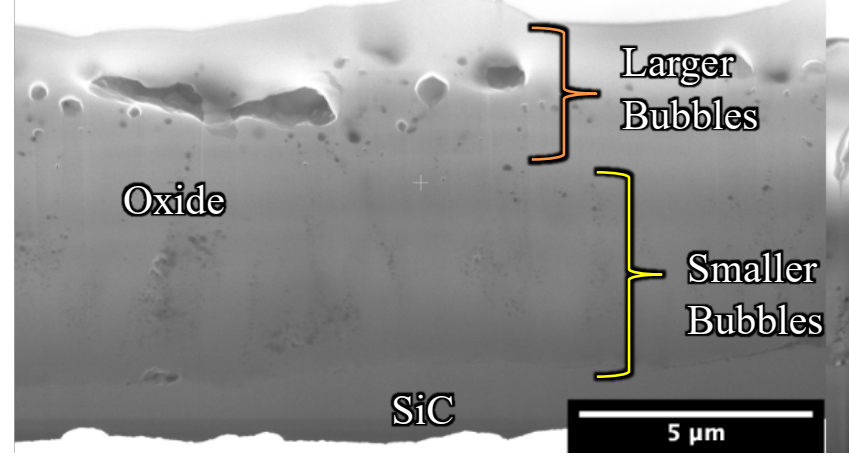

(b)

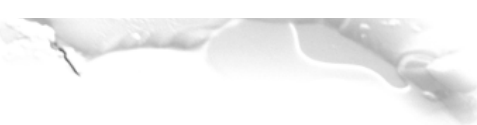

Figure 13. SEM image of the oxide layer from the (a) $400 \mathrm{~h}$ unirradiated and (b) $400 \mathrm{~h}$ irradiated samples. Small bubbles can be seen forming linear passageways radially outward towards the sample surface, while large pores are visible closer to the surface. The transition between these two bubble regions appears to be a transition between oxide regions. 
All images collected were run in the user-assisted image processing tool discussed in Section 2.3. Results are shown in Figure 14 and presented in Table 10 with the error bars representing one standard deviation of the measured data. The measured oxide thickness was reported for the primary oxide layer that was observed to be uniform around the surface of the particles. The analysis primarily focused on location away from the apparent contact points between the particle the $\mathrm{SiC}$ cup where the non-uniform secondary oxide layer was observed. The average oxide thickness was greater in the unirradiated particles for the $100 \mathrm{~h}$ exposure and generally thicker over the 50-200 h exposure range. At $400 \mathrm{~h}$ an inversion in behavior was observed as the irradiated particles showed a clear increase in oxide thickness relative to the unirradiated particles. The uncertainty in the 200 and $400 \mathrm{~h}$ exposure samples was larger for the irradiated samples, due to increased variation in measured oxide thickness present within the three locations measured within an individual particle and across the three randomly selected particles explored from each condition. It is possible that the location and distance from the nonuniform secondary oxide layer influenced the analysis and measured thickness of the uniform primary oxide layer.

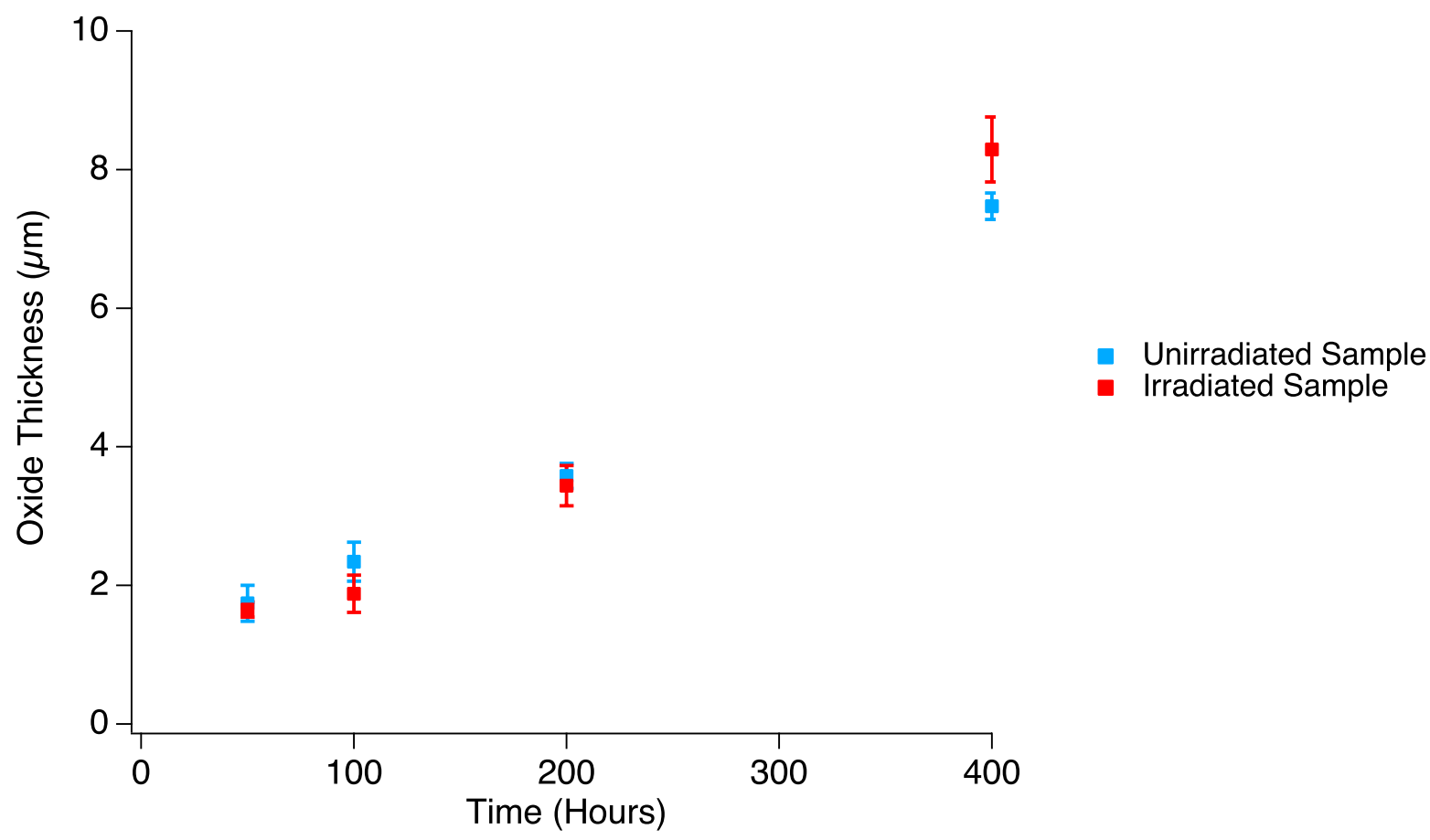

Figure 14. Oxide thickness measurements for each exposure condition.

Table 10. Oxide thickness for unirradiated and irradiated burn back particles after exposure to 50-400 $\mathrm{h}$

\begin{tabular}{ccc}
\hline Exposure Time (h) & $\begin{array}{c}\text { Unirradiated } \\
\text { Average Thickness }(\boldsymbol{\mu m})\end{array}$ & $\begin{array}{c}\text { Irradiated } \\
\text { Average Thickness }(\boldsymbol{\mu m})\end{array}$ \\
\hline $\mathbf{5 0}$ & $1.74 \pm 0.26$ & $1.65 \pm 0.11$ \\
$\mathbf{1 0 0}$ & $2.34 \pm 0.28$ & $1.88 \pm 0.27$ \\
$\mathbf{2 0 0}$ & $3.58 \pm 0.18$ & $3.44 \pm 0.29$ \\
$\mathbf{4 0 0}$ & $7.47 \pm 0.19$ & $8.29 \pm 0.47$ \\
\hline \multicolumn{3}{c}{}
\end{tabular}

At the time of reporting, scanning-transmission electron microscopy had been completed on the $50 \mathrm{~h}$ and $100 \mathrm{~h}$ irradiated and unirradiated particles using a ThermoFisher Scientific Talos F200X. The results 
showed an amorphous oxide in the unirradiated sample and a crystalline oxide in the irradiated sample. This difference in the oxide layer structure correlates with the difference in observed surface morphology in Figure 8 and Figure 9. An example of the structure and diffraction patterns of an irradiated sample from the $100 \mathrm{~h}$ test is shown in Figure 15. The TEM results indicated that the oxide layer of the irradiated samples was crystalline, but upon exposure to the $200 \mathrm{kV}$ electron beam, the oxide layer began to transform into an amorphous layer. This has been previously observed in the literature for oxidation layers on $\mathrm{SiC}$ (Terrani et al. 2014; Hobbs et al. 1994) and can make it difficult to get patterns on-axis. Energy dispersive x-ray spectroscopy (EDS) was also conducted on the TEM lamella. The EDS analysis indicated a clear division between the oxide and carbide layers, expected to be $\mathrm{SiO}_{2}$ and $\mathrm{SiC}$, respectively, and showed fission products and actinides located within the $\mathrm{SiC}$ and at the $\mathrm{SiC} / \mathrm{SiO}_{2}$ interface of the irradiated particle locations, as shown in Figure 16. Fission products were not observed in the unirradiated samples. Prior studies have shown fission product buildup at the IPyC/SiC interface in irradiated samples, with some fission products distributed across the entire SiC layer (Gerczak et al. 2018; Stempien et. al. 2021). Therefore, it is not possible to tell with certainty if the fission products observed in the irradiated samples were there after irradiation or moved there during $1400^{\circ} \mathrm{C}$ testing at this point. Figure 16 shows an EDS map of elements identified in the system. The intensity in the map displays counts above background for the characteristic x-ray lines of interest. Specifically, uranium was found at the interface of the $\mathrm{SiC}$ and $\mathrm{SiO}_{2}$, while palladium was found both at the interface and within the $\mathrm{SiC}$. No observation of aluminum or iron impurities from the alumina ceramic tubing or steel end cap and were observed in the oxide layer. Molybdenum, platinum, and gallium (not shown) were observed in all samples and are from shining from the TEM grid and holder, contamination from the protective cap deposited during sample preparation, and trace ion beam contamination (FIB artifact), respectively. There was a small gap between the oxide and silicide in the unirradiated sample that filled in with slightly more platinum than usual likely due to redeposition of the material during thinning of the TEM foil.

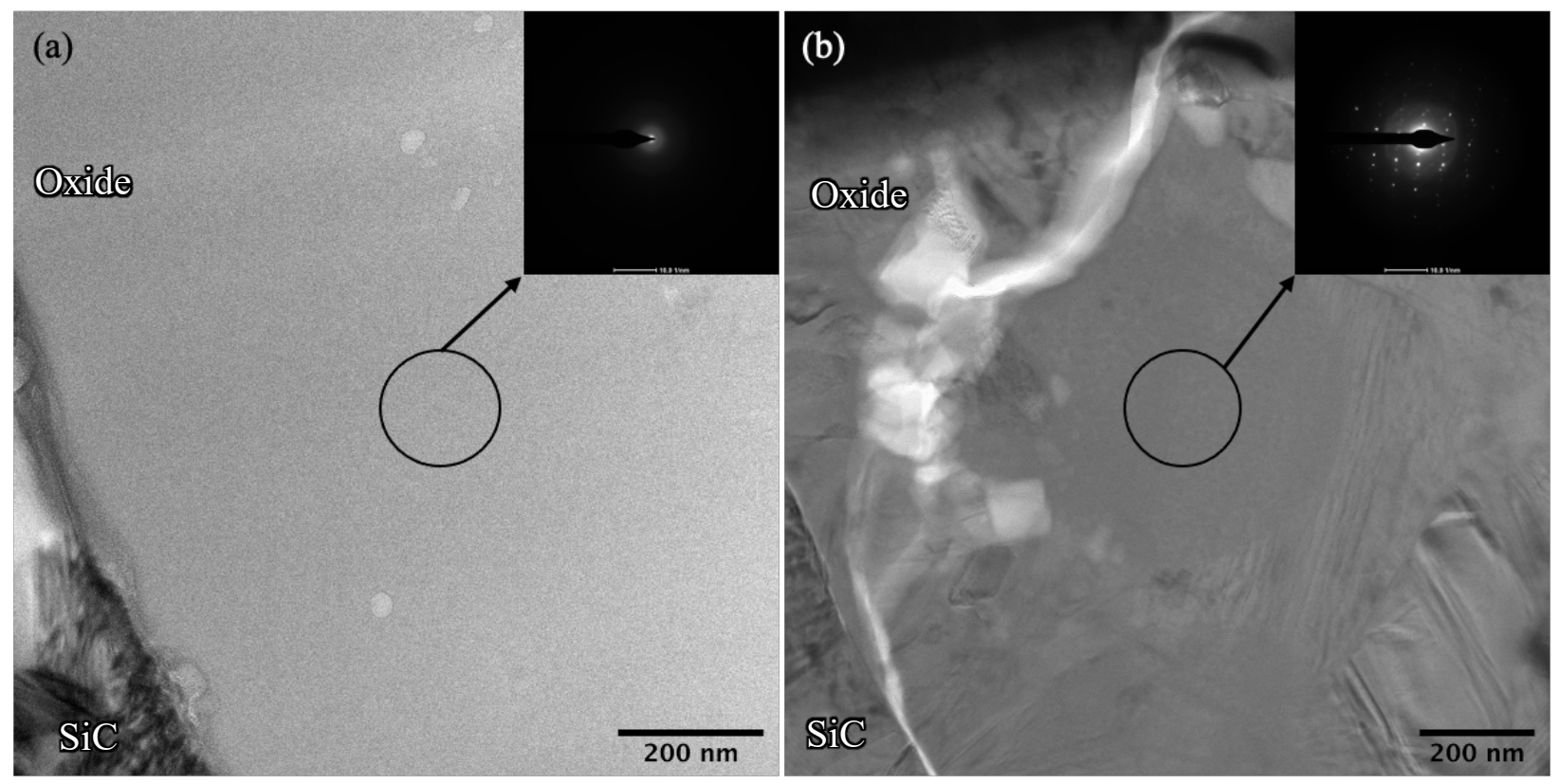

Figure 15. TEM images of the oxide regions from the (a) unirradiated and (b) irradiated samples, with corresponding diffraction patterns indicating that the unirradiated sample has an amorphous oxide layer and the irradiated sample has a crystalline oxide layer. 
(a)

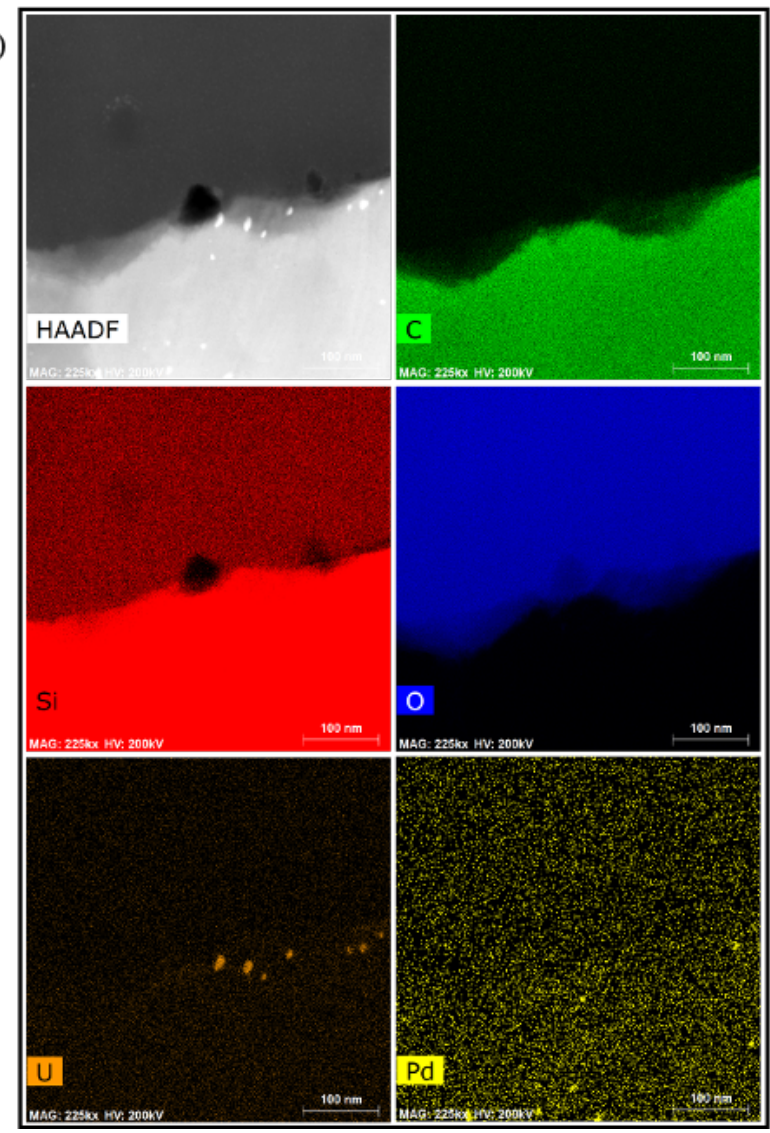

(b)

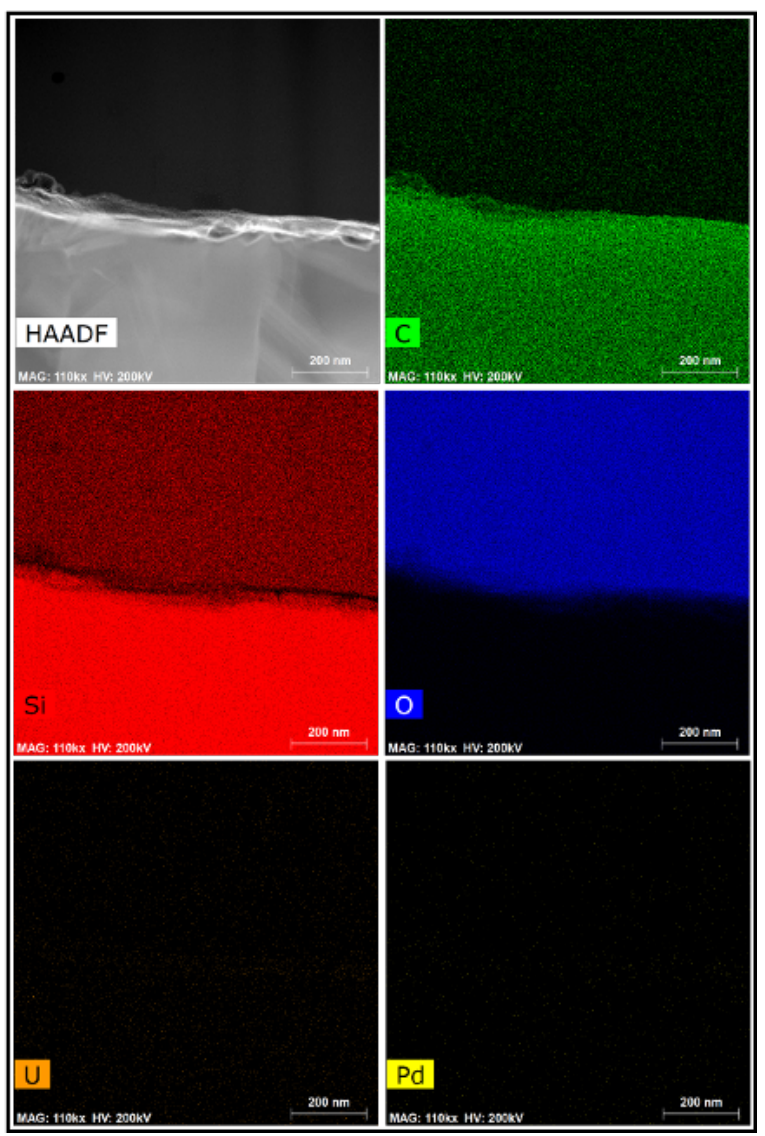

Figure 16. EDS mapping of the (a) $50 \mathrm{~h}$ irradiated sample and (b) an unirradiated sample, which show element locations within the chosen interface areas. The contrast for Pd intensity was enhanced to highlight the segregation of $\mathrm{Pd}$ in $\mathrm{SiC}$ features, the noise in the oxide region was not indicative of $\mathrm{Pd}$ presence. 


\section{DISCUSSION}

\subsection{PARTICLE FAILURE ANALYSIS}

The irradiated particle failure rate increased from the $200 \mathrm{~h}$ test to the $400 \mathrm{~h}$ test, illustrated by Figure 7 , which is consistent with previously reported loose TRISO particle oxidation studies at $1400^{\circ} \mathrm{C}$ in the KORA system (IAEA 1997). However, the failure fraction in the FITT tests, which used burned-back particles, were more pronounced related to the historic KORA TRISO tests which showed a single failure (one of ten or 10\%) after $397 \mathrm{~h}$ exposure. Ultimately the analysis indicates that particles are susceptible to increased failure during prolonged exposure to oxidizing conditions.

Unirradiated particles showed no bias for failure rate based on longer exposure times, suggesting that there were external factors leading to particle failure at this temperature. Particle failure was also observed in previous FITT experiments, in which burnback Compact 5-4-2 particles were heated in an inert atmosphere with temperatures ranging from $1150-1600^{\circ} \mathrm{C}$ (Gerczak et al. 2020). Modifications to the experimental approach were implemented prior to these oxidation tests to reduce previously theorized external causes of particle failure, such as reducing particle handling, lowering the furnace ramp rate, and temporarily dwelling at $250^{\circ} \mathrm{C}$ to drive off any moisture.

Despite efforts to minimize external factors influencing particle failure, there were inherent factors to the experimental design that could not be modified. Particle handling after DLBL and transfer from the hot cell to the FITT system were not eliminated. It is possible that transfer between containers and vacuum needle pickup/placement could have contributed to weakening the $\mathrm{SiC}$ layer. Furthermore, because the particles used in these oxidation tests underwent OPyC removal and prolonged nitric acid exposure during DLBL, it is speculated that this process could have weakened the SiC layer as well. Using particles that have not undergone burn-leach could be beneficial in future oxidation tests as the brittle SiC layer would be protected from excessive handling by the presence of the OPyC layer. Additionally, using non-burned, non-leached particles would eliminate the concern of $\mathrm{SiC}$ modification during exposure to nitric acid.

Another possibility for baseline particle failure was the interaction with the $3 \mathrm{D}$ printed $\mathrm{SiC}$ cup that held the particles during testing. Upon test capsule disassembly, it was noted that select particles were stuck to the SiC cup's wall and/or base, suggesting an interaction of the particle and cup surfaces in contact. Secondary oxide layers discovered during SEM examination (example provided in Figure 12) appeared to be the location of contact point(s) between the particle and the holder or between two particles.

\subsection{OXIDATION KINETICS EVALUATION}

The simultaneous exposure of irradiated and unirradiated burnback particles provided a direct comparison of the impact of irradiation on the SiC oxidation response. SEM analysis was able to provide thickness analysis of the uniform primary oxide on the four exposure conditions for the irradiated and unirradiated samples. Generally, the Deal-Grove model can be used to determine the linear and parabolic rate constants by simple linear regression analysis using the relationship $x=B(t / x)-A$ where $x$ is the oxide thickness, $t$ is the exposure time, $B$ is the parabolic rate constant and $A$ is the linear rate constant (Deal and Grove 1965). However, non-physical values for the linear rate constant, $A$, and low $\mathrm{R}^{2}$ values were obtained when applying this analysis to the data. This is not unexpected considering the long thermal exposure times employed in this study. Typically, oxidation studies exploring the linear-parabolic kinetics have explored oxidation behaviors over the course of tens of hours (Narushima et al. 1997) and, in some cases, deviations from parabolic behavior were observed at longer exposures (Costello and Tressler 1986). A simple treatment of the oxidation response is shown in Figure 17. For long oxidation times, parabolic oxidation rates can be determined based on the relationship $x^{2}=B t$. Simple linear regression 
can be used to determine a parabolic rate constant $\left(\mu \mathrm{m}^{2} / \mathrm{h}\right)$ when plotting the square of the oxide thickness versus exposure time. A linear fit was applied to the square of the average oxide thickness data, but it showed poor agreement when the $400 \mathrm{~h}$ data was included.

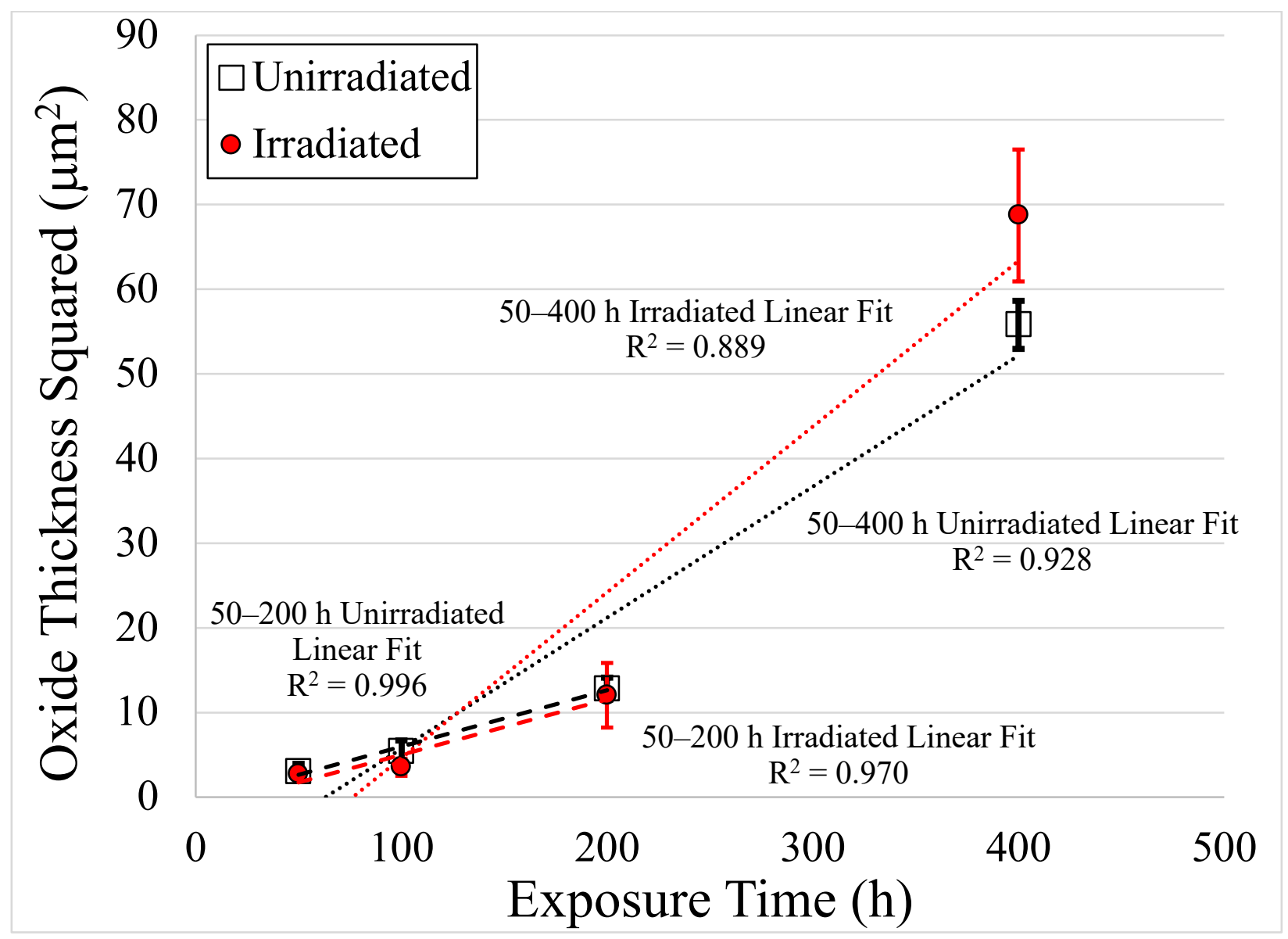

Figure 17. Oxide thickness squared vs. exposure time.

Table 11 shows the calculated parabolic rate constant over different ranges in exposure times explored in this experiment. The reduction in $\mathrm{R}^{2}$ alluded to in Figure 17 is shown numerically here and supports the conclusion that the oxidation response at $400 \mathrm{~h}$ no longer followed a parabolic oxidization behavior. One explanation for the breakdown of the parabolic behavior at longer oxidation times was reported to be due to the presence of additives in $\mathrm{SiC}$ which may impact the diffusivity in the oxide film (Costello and Tressler 1986). The deviation from a parabolic response was observed to be greater in the irradiated sample relative to the unirradiated samples. This is not unexpected for long exposure times as breakdown of the oxide layers can lead to "enhanced oxidant transport" at long exposure times as reported by Costello and Tressler (1986). The presence of apparent interconnected porosity, large pores near the oxide surface in the primary oxide layer would suggest significant change to the overall oxide structure relative to the somewhat homogenous oxide structure observed in the primary oxide layer for the shorter exposure times. When considering the irradiated versus unirradiated comparison it is speculated that the fission products in the $\mathrm{SiC}$ layer, as observed in Figure 16, may have also contributed to a higher oxidation rate beyond the parabolic regime due to enhanced diffusivity in the oxide layer. 
Table 11. Calculated parabolic rate constant, B, based on simple parabolic rate equation for different exposure ranges

\begin{tabular}{ccccc}
\hline & Unirradiated & Irradiated \\
\hline Exposure Time Range (h) & $\boldsymbol{B}\left(\boldsymbol{\mu \mathbf { m } ^ { 2 } / \boldsymbol { h } )}\right.$ & $\boldsymbol{R}^{\mathbf{2}}$ & $\boldsymbol{B}\left(\boldsymbol{\mu m}^{2} / \boldsymbol{h}\right)$ & $\boldsymbol{R}^{2}$ \\
\hline $\mathbf{5 0}-\mathbf{1 0 0}$ & 0.055 & 0.998 & 0.039 & 0.963 \\
$\mathbf{5 0 - 2 0 0}$ & 0.062 & 0.996 & 0.055 & 0.970 \\
$\mathbf{5 0 - 4 0 0}$ & 0.120 & 0.928 & 0.143 & 0.889 \\
\hline
\end{tabular}

Parabolic oxidation rate constants were reported for TRISO fuel particles at $1400^{\circ} \mathrm{C}$ by Cao et al. (2020) and Liu et al. (2014). The reported $B$ were 0.121 and $0.126 \mu \mathrm{m}^{2} / \mathrm{h}$ for Cao et al. (2020) and Liu et al. (2014), respectively, over exposure times up to $48 \mathrm{~h}$. These literature values are similar to the $B$ reported here over the full exposure range, however, the exposures at $400 \mathrm{~h}$ are noted to not follow a parabolic behavior. The $B$ of $0.055-0.062 \mu \mathrm{m}^{2} / \mathrm{h}$ over the $50-200 \mathrm{~h}$ exposure better match the $B$ reported by Cao et al. (2020) and Liu et al. (2014) at $1300^{\circ} \mathrm{C}$ of 0.042 and $0.058 \mu \mathrm{m}^{2} / \mathrm{h}$, respectively. The differences between the reported parabolic rate constants may be due to slight variation in experimental approach or temperature control.

Difference in the observed average oxidation rates at $50-100 \mathrm{~h}$ at $1400^{\circ} \mathrm{C}$ were noted between the irradiated and unirradiated particles. Notably the average oxidation rate (Table 11) was faster for unirradiated particles over these exposure times. The difference in oxidation is attributed to the different oxide layer structure present. The surface morphology analysis showed differences in oxide structure between the irradiated and unirradiated samples and TEM analysis confirmed this difference showing an amorphous oxide in the unirradiated sample and a crystalline oxide in the irradiated sample. This difference in crystal structure supports the difference in measured oxide thickness as diffusion of the oxidant was faster in the amorphous oxide layer (i.e., unirradiated) than in crystalline oxide (i.e., irradiated) (Costello and Tressler 1986). The impact of oxide structure likely competed with the influence of excess impurities (e.g., fission products) which are speculated to be a likely cause of increased diffusion in the irradiated oxide layer in the $400 \mathrm{~h}$ exposure. The cause of the greater diffusion behavior in the irradiated particles at $400 \mathrm{~h}$ may also be due to structural variation in the oxide layer. Particularly, both unirradiated and irradiated oxide layers show a variable layer structure with larger pores near the oxide surface in the primary oxide layer. Structural analysis of these layers by TEM is underway and will illuminate structural variations (e.g., amorphous versus crystalline) and pore distribution which may impact overall oxidation response at the longer exposure times where the parabolic behavior breaks down. 


\section{SUMMARY}

A FITT test chamber was designed to explore oxidation behavior of TRISO particles, and an initial study was performed to examine oxidation in simulated dry air at $1400^{\circ} \mathrm{C}$. The experiment had two areas of interest, with the first being exploration of failure fraction under oxidizing conditions. The analysis showed particle failure was sensitive to experimental design based on the baseline failure of unirradiated particles observed from 50-400 h exposures. However, the response of the irradiated particles showed a correlation of particle failure with exposure time with the greatest failure fraction observed at $400 \mathrm{~h}$. This failure response was higher than the previously reported results and suggests increased failure at $400 \mathrm{~h}$. The overall failure fraction suggests that exploration of burnback particles likely results in increased failure.

The second area of interest in this experiment was direct comparison of the influence of irradiation on oxidation response of TRISO particles. The experiment represented a direct comparison of irradiated versus unirradiated oxidation response as the particles were exposed simultaneously in the FITT. The oxidation response showed clear differences between the two particle types, specifically amorphous oxide layers in the unirradiated particles compared to crystalline oxide layers in the irradiated particles tested at 50 and $100 \mathrm{~h}$. This difference was attributed to the slower oxidation kinetics observed in the crystalline oxide layer of the irradiated particles over the 50 and $100 \mathrm{~h}$ exposures. At $400 \mathrm{~h}$ the average oxidation rate for the irradiated particles was greater than the average oxidation rate for the unirradiated particles and both particle types represented a deviation from parabolic oxidation behavior. The differences in oxidation response at these prolonged exposure times were speculated to be due to the presence of excess impurities (e.g., fission products) in the system which can impact diffusion across the oxide layer, gross changes to the oxide pore structure, and possible changes to the structure (crystalline versus amorphous) at longer exposure times. Further analysis of the structure of the respective oxide layers is required to better understand the responsible mechanisms impacting the difference in oxidation response observed in the $400 \mathrm{~h}$ exposure. The final conclusion is that the oxidation kinetics in early stages of the oxidation exposure were slower for the irradiated particles relative to the unirradiated particles, while oxidation was faster for the irradiated particles relative to the unirradiated particles as the oxidation response deviated from a parabolic behavior at extended oxidation exposures. 


\section{REFERENCES}

Cao, Fangcheng, D, Zhang, Q. Chen, H. Li, and H. Wang. 2020. "Evaluation of Oxidation Performance of TRISO Fuel Particles for Postulated Air-Ingress Accident of HTGR.” Journal of Chemistry 2020, Article ID 6568987: 8 pages. doi: 10.1155/2020/6568987.

Costello, J.A., and R.E. Tressler. 1986. "Oxidation Kinetics of Silicon Carbide Crystals and Ceramics in Dry Oxygen.” Journal of the American Ceramics Society 69 [9]: 674-681.

Deal, B.E., and A.S. Grove. 1965. "General Relationship for the Thermal Oxidation of Silicon." Journal of Applied Physics 36 (12): 3770-3778. doi: 10.1063/1.1713945.

Demkowicz, P.A., J.D. Hunn, R.N. Morris, I.J. van Rooyen, T.J. Gerczak, J.M. Harp, and S.A. Ploger, 2015. AGR-1 Post Irradiation Examination Final Report, INL/EXT-15-36407, Revision 0. Idaho Falls: Idaho National Laboratory. doi:10.2172/1236801.

Gerczak, T.J., J.D. Hunn, R.N. Morris, F.C. Montgomery, D.J. Skitt, C.A. Baldwin, J.A. Dyer, and B.D. Eckhart. 2018. "Analysis of Fission Product Distribution and Composition in the TRISO Layers of AGR-2 Fuel." Proc. 9th International Topical Meeting on High Temperature Reactor Technology (HTR-2018). Warsaw, October 8-10, 2018. Also published in Nuclear Engineering and Design 364: 110656. doi: 10.1016/2020/110656.

Gerczak, T.J. 2019. Standard Operating Procedure for Individual TRISO Particle Heating Tests, NFMPIE-SOG-01, Revision 2, Oak Ridge National Laboratory.

Gerczak, T.J., Z.M. Burns, D.J. Skitt, R.N. Morris, and J.D. Hunn, 2020. AGR 2 loose particle heating tests in the furnace for irradiated TRISO testing, ORNL/TM-2020/1715-R0. Revision 0. Oak Ridge: Oak Ridge National Laboratory.

Hobbs, L.W., F.W. Clinard Jr., S.J. Zinkle, and R.C. Ewing. 1994. "Radiation Effects in Ceramics.” J. Nucl. Mater. 216: 291-321.

Hunn, J.D., F.C. Montgomery, and P.J. Pappano. 2010. Data Compilation for AGR-2 UCO Variant Compact Lot LEU09-OP2-Z, ORNL/TM-2010/017, Revision 1. Oak Ridge: Oak Ridge National Laboratory.

Hunn, J.D., R.N. Morris, C.A. Baldwin, F.C. Montgomery, C.M. Silva, and T.J. Gerczak. 2013. AGR-1 Irradiated Compact 4-4-2 PIE Report. ORNL/TM-2013/236, Revision 0. Oak Ridge: Oak Ridge National Laboratory.

Hunn, J.D., C.A. Baldwin, T.J. Gerczak, F.C. Montgomery, R.N. Morris, C.M. Silva, P.A. Demkowicz, J.M. Harp, S.A. Ploger, I.J. van Rooyen, and K.E. Wright. 2016. "Detection and Analysis of Particles with Failed SiC in AGR-1 Fuel Compacts." Nucl. Eng. Des. 360 (2016): 36-46.

Hunn, J.D., T.J. Gerczak, F.C. Montgomery, D.J. Skitt, C.A. Baldwin, G.W. Helmreich, B.D. Eckhart, and J.A. Dyer. 2018. AGR-2 As-Irradiated UCO Compact 5-4-2 PIE Report, ORNL/TM 2018/863, Revision 0. Oak Ridge: Oak Ridge National Laboratory. 
Hunn, J.D., T.J. Gerczak, F.C. Montgomery, D.J. Skitt, R.N. Morris, G.W. Helmreich, B.D. Eckhart, and Z.M. Burns. 2019. Safety Testing and Destructive Examination of AGR-2 UCO Compact 2-1-2, ORNL/TM-2019/1201, Revision 0. Oak Ridge: Oak Ridge National Laboratory.

International Atomic Energy Agency. 1997. Fuel performance and fission product behaviour in gas cooled reactors. IAEA-TECDOC-978. Vienna: International Atomic Energy Agency.

Moormann, R. 2011. "Phenomenology of Graphite Burning in Massive Air Ingress Accidents." Science and Technology of Nuclear Installations 2011, Article ID 589747 (2011): 13 pages. doi:10.1155/2011/589747.

Narushima, T., T. Goto, T. Hirai, and Y. Iguchi. 1997. "High-Temperature Oxidation of Silicon Carbide and Silicon Nitride." Materials Transactions, JIM 38 (10): 821-835.

Opila, E. 1995. "Influence of Alumina Reaction Tube Impurities on the Oxidation of Chemically-VaporDeposited Silicon Carbide." Journal of the American Ceramic Society 78 (4): 1107-1110.

Presser, V., and K.G. Nickel. 2008. "Silica on Silicon Carbide." Critical Reviews in Solid State and Materials Sciences 33 (1): 1-99. doi: 10.1080/10408430701718914.

Singhal, S.C., and F.F. Lange. 1975. "Effect of Alumina Content on the Oxidation of Hot-Pressed Silicon Carbide." Journal of the American Ceramic Society 58 (9-10): 433-435.

Stempien, J.D., J.D. Hunn, R.N. Morris, T.J. Gerczak, and P.A. Demkowicz, 2021. AGR-2 TRISO Fuel Post-Irradiation Examination Final Report, INL/EXT-21-64279, Revision 0. Idaho Falls: Idaho National Laboratory.

Sterbentz, J.W. 2014. JMOCUP As-Run Daily Depletion Calculation for the AGR-2 Experiment in the ATR B-12 Position, ECAR-2066, Revision 2. Idaho Falls: Idaho National Laboratory.

Terrani, K.A., B.A. Pint, C.M. Parish, C.M. Silva, L.L. Snead, and Y. Katoh. 2014 "Silicon Carbide Oxidation in Steam up to 2 MPa." J. Amer. Ceram. Soc. 97(8): 2331-2352. 
